\title{
EXISTING AND PROPOSED URBAN GEOSITES VALUES RESULTING FROM GEODIVERSITY OF POZNAŃ CITY
}

\author{
Zbigniew Zwoliński, Iwona Hildebrandt-RadKe, MaegorZata MaZureK, \\ MiroseaW MAKOHONIENKO
}

Institute of Geoecology and Geoinformation, Adam Mickiewicz University in Poznań, Poland

Manuscript received: 30 July 2017

Revised version: 15 September 2017

\begin{abstract}
Zwoliński Z., Hildebrandt-Radke I., Mazurek M., Makohonienko M., 2017. Existing and proposed urban geosites values resulting from geodiversity of Poznań City. Quaestiones Geographicae 36(3), Bogucki Wydawnictwo Naukowe, Poznań, pp. 125-149. 15 figs, 2 tables.

Aвstract: Poznań, a city in central-western Poland, is located in the lowland region but has no less attractive geomorphological and human history. It was here that Poland was born at the end of the tenth century. The city's location is connected with the meridian course of the Warta River valley. In contrast, in the northern part of the city, there is a vast area of the frontal moraines of the Poznan Phase of the Weichselian Glaciation. Against the backdrop of the geomorphological development of the city, the article presents the existing geosites, classified as urban geosites. The present geosites include three lapidaries with Scandinavian postglacial erratics, one of them also with stoneware, a fragment of a frontal push moraine and impact craters. Besides, three locations of proposed geosites with rich geomorphological and/or human history were identified. These are as follows: the peat bog located in the northern part of the city, defence ramparts as exhumed anthropogenic forms, and the Warta River valley. The existing and proposed geosites in Poznań were evaluated in three ways. In general, it should be assumed that the proposed new geosites are higher ranked than the current ones.
\end{abstract}

KEY WORDS: urban geosite, geodiversity, geoheritage, cultural heritage, Poland

Corresponding author: Zbigniew Zwoliński, zbzw@amu.edu.pl

\section{Introduction}

Geographical environment of Poznań has been researched for at least 100 years, which has resulted in documenting its rich geodiversity and biodiversity. It includes urban protected areas, although their existence and history of academic research are much shorter. The protected areas of Poznań are so young that they have neither systemic management nor integrated monitoring. Among the objects and protected areas of Poznan are the geosites, whose ideas in general context are promoted by Reynard (2004). Geosites in urbanised areas are relatively rarely introduced as forms of inanimate nature conservation, and as a consequence are often not noticed by both residents and naturalists, including academics and tourists. Alexandrowicz (2003), in her list of geosites of Poland for the European geosites network, does not distinguish urban geosites. Urban geosites have recently been noticed, and more attention is paid to them (Reynard et al. 2017). Undoubtedly, underestimation is due to the existence of dense urban development, communication networks, and even areas of green infrastructure that can obscure urban geosites. As a result, they are missed out as objects of natural 
and cultural heritage. The Earth Summit in Rio de Janeiro (1992), and the emphasis on the sustainable development of the environment and society, has given a clear impulse to the protection of the objects of nature that had so far been irretrievably lost in urban areas mainly because of the existence of grey infrastructure. In turn, the development of the concept of green and blue infrastructure has allowed for better solving the problems of shaping and protecting the natural environment in cities. These actions also help protect geoheritage in urban areas (cf. Reynard et al. 2017).

Urban geosites usually occupy small areas of terrain, and their location depends on the size of the city, its population as well as its spatial structure. Hence, few such items exist in town centres, while many more can be found on the outskirts of cities where there are more open spaces. Urban public spaces contribute to the visibility and protection of the city's geodiversity in the form of geosites.

The situation is similar in Poznań, a city located in central-western Poland, on the Warta River, where the Polish state was formed. The article aims to present the urban geosites existing in Poznan, and then to propose new urban geosites on the geomorphic background of the city. The other goal of the paper is to apply two measures evaluating urban geosites and compare their results in the context of geosites protection and management.

The most important factors for the location of the settlement and then the development of the city of Poznan include the location on the Warta River. The topography of the city is inscribed in the natural layout of the landforms connected with the formation of the Warta River valley. For hundreds of years, people have been transforming natural landforms and the local river network, adjusting the occupied land for settlement purposes. Nowadays, the extent of urban transformation is significant, and the accessibility to research in these areas is limited by the size of centuries-old buildings, so it is practically impossible to recognise the change of landforms entirely. Hence, in urban areas, places which deserve to be called a geosite occur either in excavations or filled-in pits. Therefore, the delimitation of visible and invisible geosites by Clivaz and Reynard (2017) seems reasonable.

\section{Geodiversity of Poznań City}

Despite the lowland character of the Wielkopolska (Great Poland) region, where Poznan has been developing (on the regional scale, on the Polish Lowland within North European Plain), its terrain shows exceptional diversification (Fig. 1). The largest part of Poznan is taken by the moraine plateau, which is the effect of the last Scandinavian ice sheet, namely the Poznań Phase of the Weichselian (Vistulian) Glaciation (Kozarski 1995), on which forms of frontal and areal deglaciation have been imposed (Fig. 2). The moraine plateau reaches an average elevation of 80-100 $\mathrm{m}$ a.s.l. In the northern part of the city the more varied relief is associated with the area of undulating moraine plateau (altitude 90-100 $\mathrm{m}$ a.s.l, slopes $8-16^{\circ}$ ), and the hills and ramparts of the frontal accumulative and glaciotectonic push moraines (Krygowski 1961). The relative heights of these formations with respect to the upland is ca. $50 \mathrm{~m}$, while to the bottom of the Warta River - ca. $100 \mathrm{~m}$. The dominant elevation is Morasko Hill (153.75 m a.s.l.). In contrast, the southern and western parts of the city stretch out on the flat moraine plateau (altitude 80-85 m a.s.l., slopes 0-0.5) (Żynda 1996). The moraine plateau is dissected by numerous concave forms in the shape of subglacial valleys and erosional lateral river valleys, whose slope range is $1-4^{\circ}$. These forms show the NE-SW (Cybina and Główna valleys) and NW-SE (valleys of Junikowski Stream, Bogdanka Stream and Różany Stream) orientation. Moreover, endorheic basins of different genesis and sizes are numerous.

However, the most important and largest form of the meridional course is the Warta River, in its gap section. Within the limits of Poznan, the south-north part of the Warta River valley reaches a length of $15 \mathrm{~km}$, while the width varies from 3 $\mathrm{km}$ at the southern end of the city to $1.5 \mathrm{~km}$ in the northern end (Fig. 1). On average, the valley cuts the moraine plateau 20-40 m down. Pawłowski (1929) describes four terraces in the Warta River valley: the floodplain, the lower terrace (2 to $6 \mathrm{~m}$ ), the central terrace (7-12 $\mathrm{m}$ ) and the upper terrace (15(17)-21 m). The concept of the Warta terraces system was developed by Bartkowski (1957), which will be further discussed. On the lowest floodplain in the bottom of the Warta River, on 


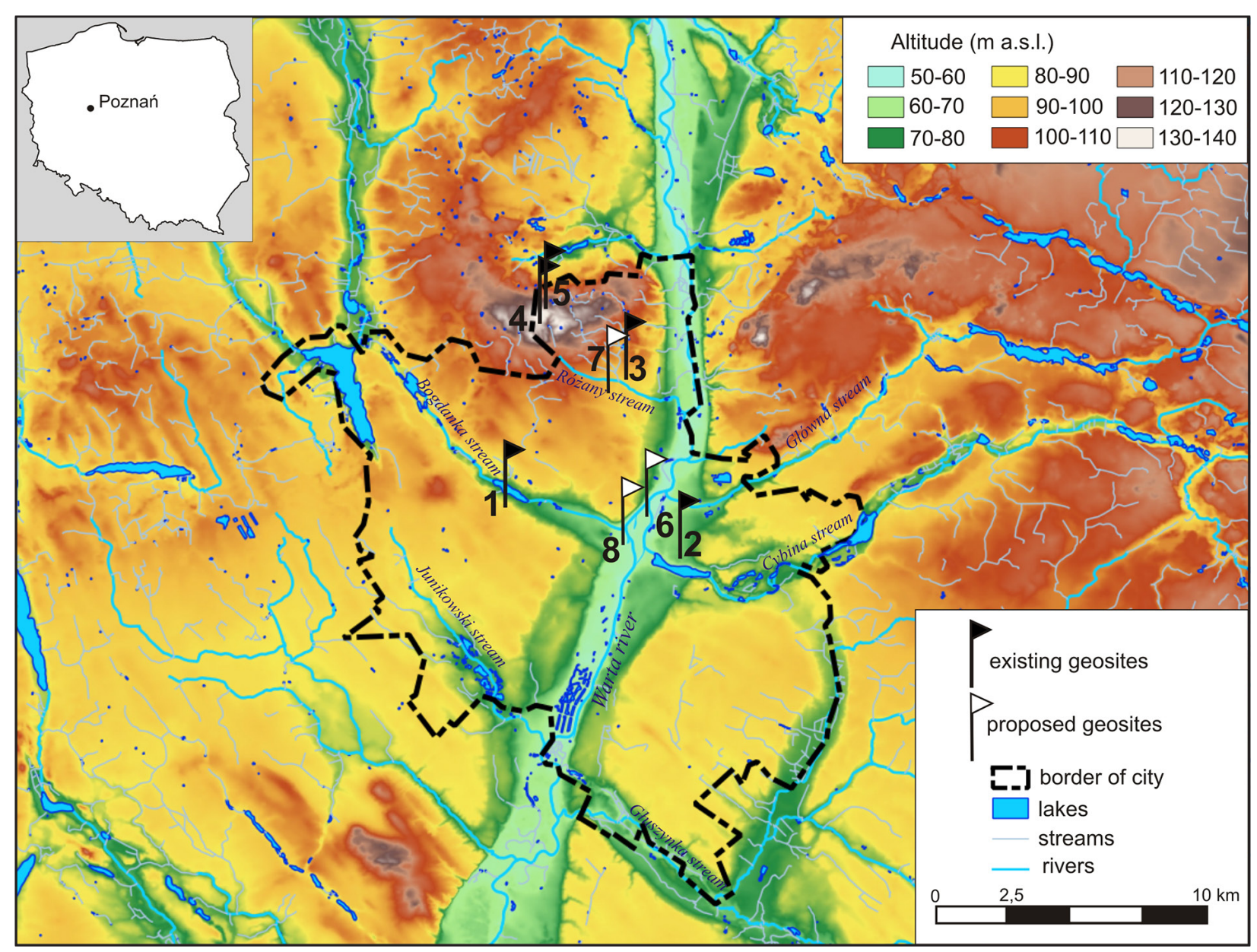

Fig. 1. Digital elevation model and main elements of hydrographic network for Poznań vicinity (DEM elaborated on the basis of Vmap Level 2 by J. Jasiewicz) with existing and proposed geosites.

1 - Lapidarium in the Botanical Garden, 2 - Lapidarium in the Millennium Park, 3 - Lapidarium at the Institute of Geology, 4 - Morasko Hill, 5 - Impact Crater Morasko, 6 - Genius Loci, 7 - Żurawiniec peat bog, 8 - Poznań section of the Warta River Valley.

the islands in the riverbed of the anastomosing river, the site of Poznań, considered to be the beginning of the Polish state (Kóčka-Krenz 2015a), was located at the end of the tenth century. On the second left bank meadow terrace, the location of medieval Poznań (Kóčka-Krenz 2015b) commenced in 1253.

The area of Poznan lies on the border of two geological-tectonic units: the Fore-Sudetic Monocline and the Szczecin-Łódź-Miechów Syncline (Pożaryski 1974). Older geological structures are built of Permian series folded during the Variscan orogeny. The next series contains younger Permian and Mesozoic rocks inclined to the north and northeast. Numerous faults are associated with Paleogene and Neogene tectonic horsts and grabens (Grocholski 1991). One of these tectonic grabens is used by the Poznan Warta Gap, which passes south-north through the central part of the city (Pawłowski 1929) (Fig. $3)$. The varied pre-Cenozoic relief was covered with nearly 250 meters of an almost horizontal layer of Neogene clay, mud and sand with alternating lignite (Ciuk 1978, Chmal 1997). Of particular importance for the Poznan area are the Pliocene motley clays up 110 m thick (Dyjor 1970, Kunkel 1975), often exposed in glaciotectonic structures (Krygowski 1961), for instance on the Warta River valley slopes (Chmal 1997).

Quaternary series of sediments, whose thickness reaches a maximum of $60 \mathrm{~m}$, come from successive Scandinavian glaciations that covered the Polish territory. They are represented by glacial till beds separated by fluvioglacial and ice-dammed sands and gravels of the Great and Eemian Interglacials (Chmal 1997). The marginal zone of the Poznan Phase of the Weichselian Glaciation, which runs east-west across the city, 

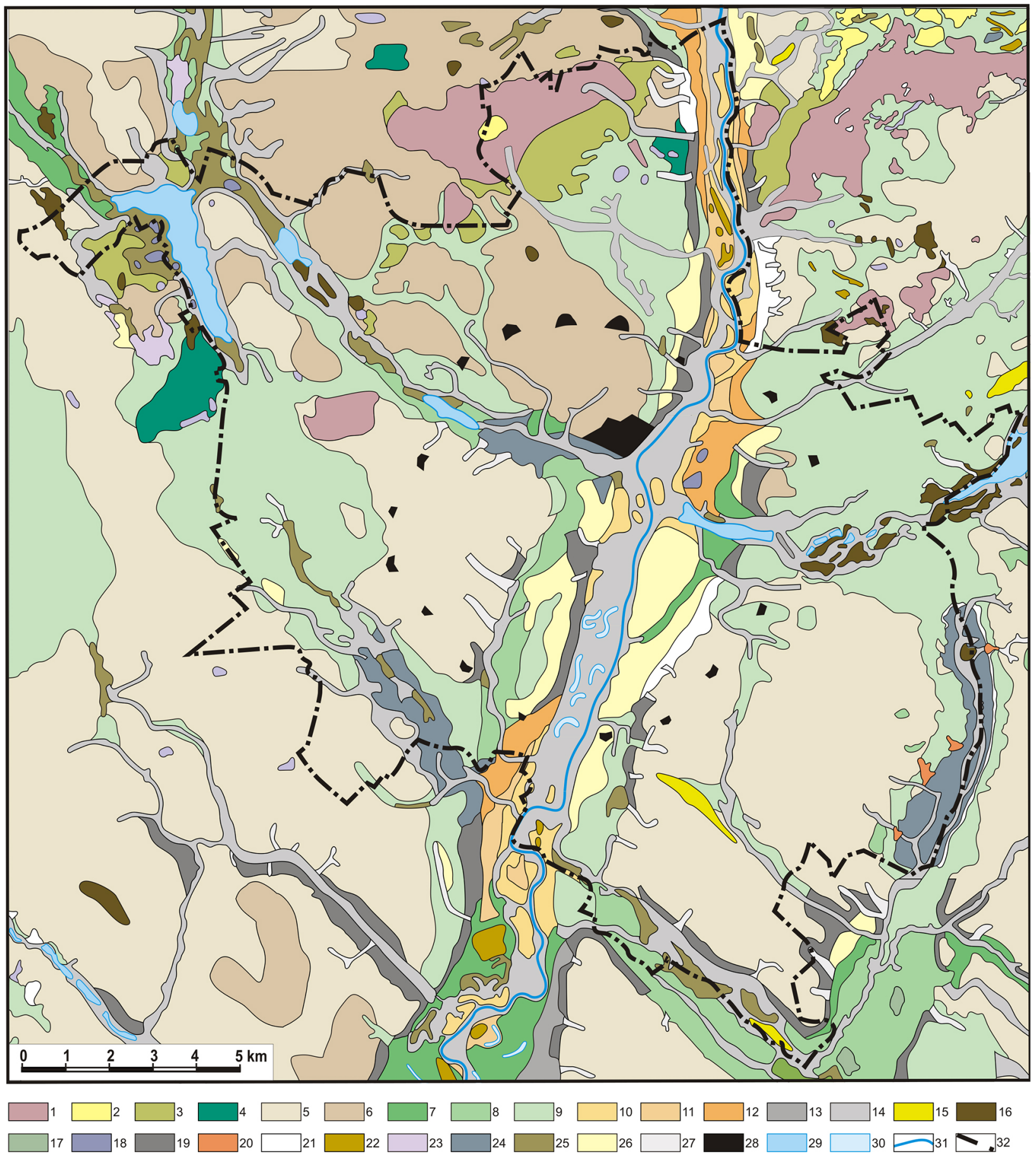

Fig. 2. Geomorphological map of Poznan area (Hildebrandt-Radke 2016, elaborated on the basis of previous geomorphological maps acc. Bartkowski 1957, Tomaszewski 1960, Krygowski 1961, and geomorphological sketches attached to the Detailed Geological Map of Poland by Chmal 1992, 1996, 1997, Bartczak 1993, Gogołek 1993, Chachaj 1996, Cincio 1996, Sydow 1996; modified).

1 - morainic hills of accumulation origin, 2 - morainic hills of glacitectonic origin, 3 - accumulative morainic hills, 4 - ice-death morainic hills, 5 - flat morainic upland, 6 - undulating morainic upland, 7 - highest outwash level, 8 - higher outwash level, 9 - lowest outwash level, 10 - $1^{\text {st }}$ erosion-accumulation terrace, $11-2^{\text {nd }}$ erosion-accumulation terrace, 12 - accumulation terrace , 13 - ice-marginal valley terrace, 14 - bottom of valley, 15 - eskers, 16 - kames and kame terraces, 17 - denudation plains, 18 - alluvial remnants, 19 - slopes, 20 - alluvial fans, 21 - slope wash plains, 22 - aeolian sands, 23 - lacustrine plains, 24 - glaciolacustrine plains, 25 - peat plains, 26 - erosion plains of meltwaters, 27 - valley, 28 - forts, 29 - lakes, 30 - dry and wet oxbow lakes, 31 - rivers, 32 - border of city. 

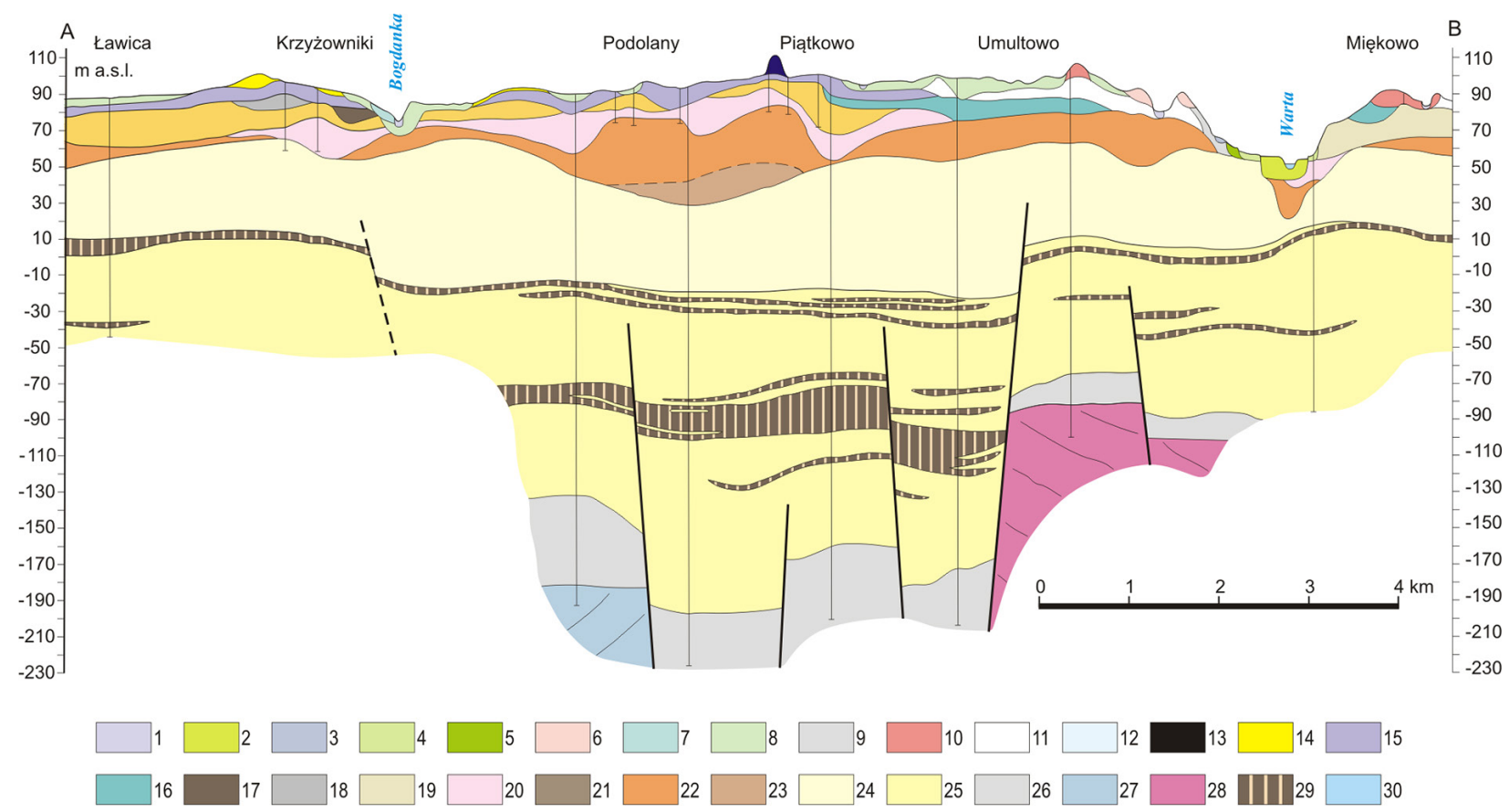

Fig. 3. Geological cross-section of the Warta River valley in Poznań (elaborated on the basis of Detailed Geological Map of Poland by Chmal 1996).

1 - sandy muds of the valley bottom, 2 - alluvial sands of the floodplain 2.5-4.5 m above the river level, 3 - slope wash sands on the clays and muds, 4 - sands and gravels of upper terraces from Bølling, 5 - alluvial sands and gravels of upper terraces of the Pomeranian Phase, 6 - glaciofluvial sands and gravels of ice-death moraine, 7 - glaciofluvial sands and gravels of the $3^{\text {rd }}$ outwash level of the Poznan Phase, 8 - glaciofluvial sands and gravels of the 1st outwash level of the Poznań Phase, 9 - sands, gravels, locally glacial boulders of the Poznań Phase, 10 - end-moraine sands and gravels of the Poznań Phase, 11 - tills of the Poznań Phase, 12 - lacustrine clay and muds of the Poznań Phase,

13 - sands and gravels of kames of the Poznań Phase, 14 - glacial sands on the tills of the Leszno Phase, 15 - tills of the Leszno Phase, 16 - lower glaciofluvial sands and gravels of the Leszno Phase, 17 - muds and peats of Eemian Interglacial Stage, 18 - glaciofluvial sands and gravels of the Warta Stadial, 19 - tills of the Warta Stadial, 20 - glaciofluvial sands and gravels of the Odra Stadial, 21 - glaciolacustrine clays, muds and sands of the Odra Stadial, 22 - tills of the Odra Stadial, 23 - tills of the South Polish Glaciation, 24 - Neogene clays, muds and sand, 25 - Neogene sands, clays, muds and brown coal, 26 - Palaeogene sands, clays, muds and brown coal, 27 - Upper Jurassic marls, limestone and clays, 28 - Lower Jurassic sandstones, clays and marl limestone, 29 - brown coal, 30 - rivers.

developed ca. 18400 years BP, and the youngest till deposits are up to $12 \mathrm{~m}$ thick (Kozarski 1995). The southern parts of the today's Poznan stretch on three levels of the outwash plain (Krygowski 1961, Biedrowski 1968). Locally, sands and gravels of eskers, kames and kame terraces as well as ice-dammed clay (Bartkowski, Krygowski 1959, Chmal 1997) also occur.

In the Holocene, surface sediments were modified while landforms were transformed and levelled through denudation processes. Quaternary postglacial deposits and Holocene colluvial and alluvial sediments were a good substrate for the development of lessive, proper brown, leached brown and brown acidic soils on moraine plateaus, black earths on wetlands, podzolic and rusty soils on outwash plain sands, as well as mud-peat, peat, marshy-peat, marshy-mineral and alluvial soils in river valleys, subglacial channels and around lakes.

In the Holocene intensive lateral erosion processes led to the development of an extensive floodplain and the destruction of higher terraces (Bartkowski 1957). At the bottom of the Warta River valley, there were frequent changes of the main river channel pattern caused by floods (Kaniecki 2004, 2013) from a multi-channel river with numerous islands (anastomosing river) to a modern-day single-channel river (meandering river but in the centre of Poznan with the anthropogenically straightened course). In addition to planar changes, hypsometric changes in plus and minus in the bottom of the valley, as well as individual terraces, are significant (Fig. 4). It demonstrates the complex transformations of the relief in the river valley, both horizontal and vertical, 
as well as temporal. The remains of the upper terraces (e.g., terrace VII), which rise above the lower terraces are called "hills" (Kaniecki 2013).

The geomorphological landscape of Poznań has changed many times since the Middle Ages. It was connected with frequent human interventions, first in the relief of the bottom of the Warta River valley (Fig. 4), later also meadow terraces and moraine plateaus. The effect of these interventions is the creation of an extensive inventory of anthropogenic forms and sediments. These

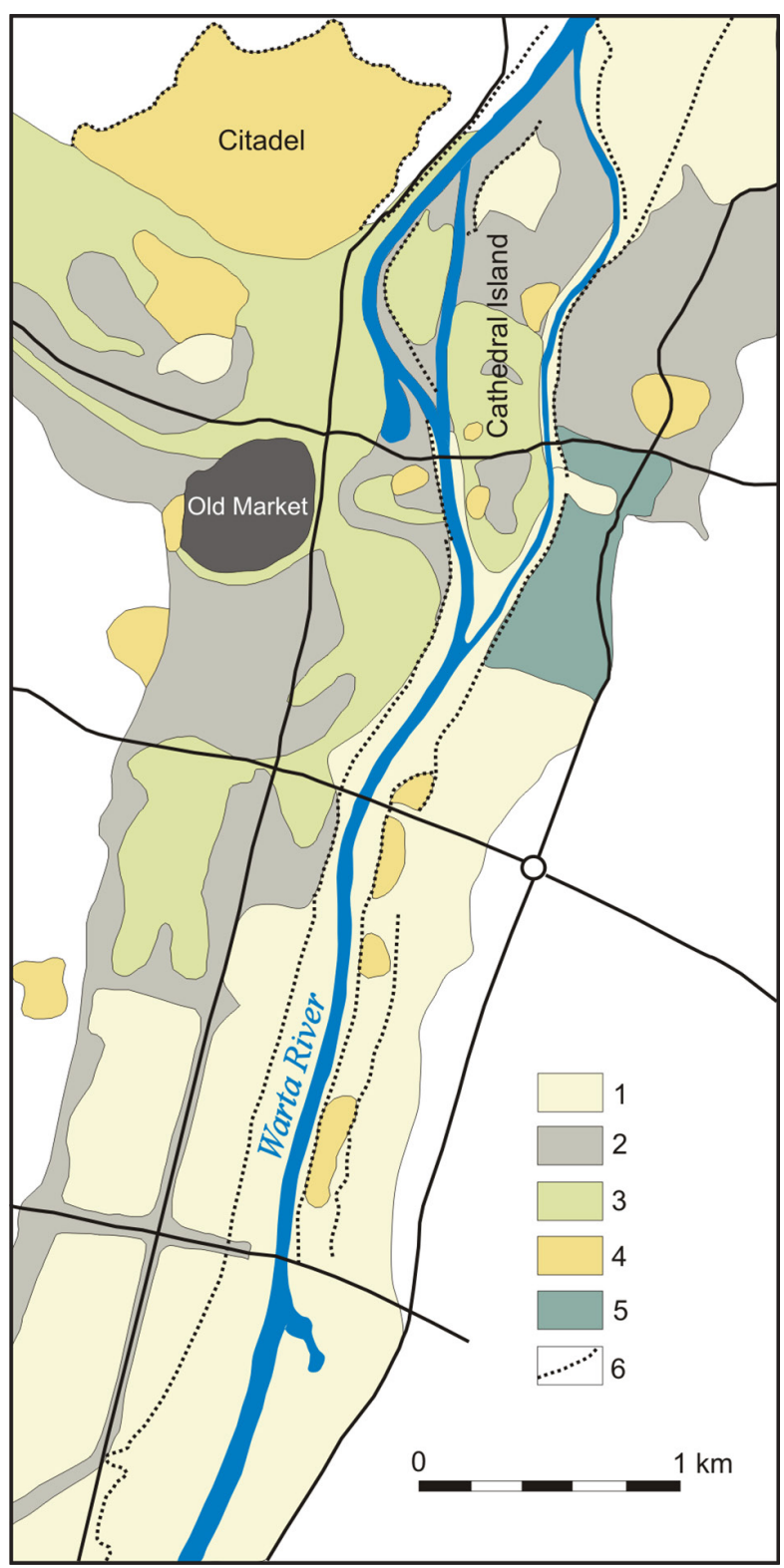

Fig. 4. Hypsometric changes of terrain surface as a result of levelling out works along the Warta River valley (Kaniecki 2013).

1 - raising by $0-2 \mathrm{~m}, 2$ - raising by $2-5 \mathrm{~m}, 3$ - raising above $5 \mathrm{~m}, 4$ - lowering the terrain surface, 5 - lowering, then raising the terrain surface, 6 - steep slopes. forms, together with the deposits forming them, create the contemporary cultural landscape of Poznań. The forms created by human activity include, first of all, levelling of the river terraces by superimposing sediments, levelling of river terraces and small hills by removing deposits, flood embankments, moats, communication dykes, earthworks, filling in river and stream beds and old canals, fortifications, disused excavation pits of glacial till, varved clay and sand, artificial water reservoirs, communication embankments and ditches, agricultural terraces, high bounds, field road incisions, reclaimed municipal landfills. These forms refer strictly to the genetic classification of anthropogenic forms proposed by Kirchner, Smolová (2010), Szabó et al. (2010) and Kubalíková et al. (2017). The emergence of these forms in many places has resulted in the increase of cultural layers of 5-7 $\mathrm{m}$ in thickness over the last millennium, with the raising of 3-5.5 m (Kaniecki 2013) in the first 300 years (Fig. 4). Such a high terrain raising in the Warta River valley was due to the frequent floods and inundations of the areas occupied by the buildings. The material used for shaping anthropogenic forms was a mixture of native sediments, mainly sand, less often till, and additives related to human activities, such as debris and litter.

\section{Existing geosites}

The Polish Central Register of Geosites of the National Geological Institute includes 2200 geosites $^{1}$ across the entire country (Warowna et al. 2013, Chybiorz, Kowalska 2017, PGI 2017). It contains six geosites in Poznań (see Fig. 1, black flags). The analysis in this article, however, covers only five of them. The sixth geosite excluded from this article is a single boulder at the entrance to another geosite, namely the Morasko Meteorite Reserve. Thus, instead of distinguishing a single boulder, it should be incorporated into the Impact Crater Morasko geosite or be designated as a natural monument.

Moreover, there is an English version of the geosites register in Poland, namely "Database of Polish Representative Geosites" created by the Institute for Nature Conservation of the Polish Academy of Sciences (http://www.iop.krakow.pl/geosites/), which includes a mere 176 geosites. 


\section{Lapidaries}

Several Scandinavian ice sheets advancing into the Wielkopolska area eroded many blocks and boulders from the Scandinavian territories and the Baltic basin, and incorporated them into the long-distance glacial transport. Spreading ice sheets extracted igneous, metamorphic and sedimentary rocks. The magmatic and metamorphic rocks dominating erratics come from the crystalline Fennoscandian (Baltic) Shield. The outcrops of sedimentary rocks are located in the plate built of Neoproterozoic, Lower Palaeozoic, Upper Mesozoic and Lower Cainozoic sedimentary rocks which cover the Fennoscandian Shield (Czubla et al. 2006, Górska-Zabielska 2008). Thus, the rock material from northern Europe can be up to 1.8 billion years old.

The boulders of Wielkopolska belong to the natural resources of the lithosphere. They form a trace of subsequent Scandinavian glaciations and are the geological heritage of the region. They represent different petrographic types and come from different feeding areas. They indicate the direction of the transgression of the ice sheet and/or ice streams (Górska-Zabielska 2008) and may be the basis for determining the age of glacial sediments. All these characteristics indicate that boulders are undoubtedly an element of the region's geodiversity.

Boulders are one of the unique features of the natural environment, hence the efforts to preserve this kind of inanimate nature heritage in the form of a collection of boulders in a petrographic garden, otherwise called a lapidarium. Lapidaries can, therefore, be treated as geosites. A classic example of such geosites are the specimens described from the Turin area of Piedmont, Italy (Motta, Motta 2007). There are three lapidaries in the Polish Central Register of Geosites (PGI 2017) located in Poznań which were created to preserve and protect the stone remnants of Pleistocene glaciations in the geographical environment, and cultural heritage.

\section{Lapidarium in the Botanical Garden}

The Botanical Garden of the Adam Mickiewicz University is located in the moraine plateau in the western part of Poznań (see Fig. 1, flag 1). In the background of the collection of plants and trees are exposed boulders, enriching the area with geotourist attractions. The rock material of about 3000 tons consists of ten boulders in different parts of the garden. The geosite is registered in the Polish Central Register of Geosites under the number KDG: 1250 and the name "Erratics in the Botanical Garden of the Adam Mickiewicz University in Poznań". These boulders represent all petrographic types of rocks. They have been exposed $e x$ situ, i.e., outside of their original occurrence, but still bear witness of geodiversity of the NW Poland (Górska-Zabielska 2010, 2013). There are two large boulders from the very area of Poznań: the gneiss (from the Rataje District on the right bank of the Warta River) and the Smaland granite (from the Wilda District on the left bank of the Warta River). The original deposition site of these boulders is the evidence of their glacial transport during the Leszno Phase of the Weichselian Glaciation (ca. 20000 years ago, Górska-Zabielska 2013). Other boulders are guide erratics: Karlshamn granite, Stockholm granite and grey Vaxjo granite. The Botanical Garden has the largest gneiss boulder in Poznań (Fig. $5 \mathrm{~B}$; length $4.5 \mathrm{~m}$, width $4.2 \mathrm{~m}$, height 5.5 $\mathrm{m}$, circumference $12 \mathrm{~m}$, volume $54.4 \mathrm{~m}^{3}$, weight 149,5 tons; Górska-Zabielska 2010, 2015). The boulders in the Botanical Garden show unusual morphology because they have traces of polishing that the rock gained during glacial transport (glacial polish), as well as surfaces smoothed by sandblasting (eologliptolites). Access to the boulders is easy and safe; unfortunately these objects are not adequately described.

\section{Lapidarium in the Millennium Park}

A collection of boulders of the Millennium Park is located in the eastern part of Poznan (see Fig. 1, flag 2). The geosite is registered in the Polish Central Register of Geosites under the number KDG: 1251 and the name "Erratics in the Millennium Park on Lake Malta in Poznań". There are about 30 boulders in the park (Fig. $5 \mathrm{~A}$ ), excavated during the creation of the artificial basin of Lake Malta. These are not objects occurring precisely in the in situ position, i.e., in the position where they were deposited by the ice sheet. They were moved to a short distance, documenting the composition of post-glacial sediments of the Leszno Phase of the Weichselian Glaciation, building the moraine plateau in the eastern part of Poznan. Among the boulders there are guide 

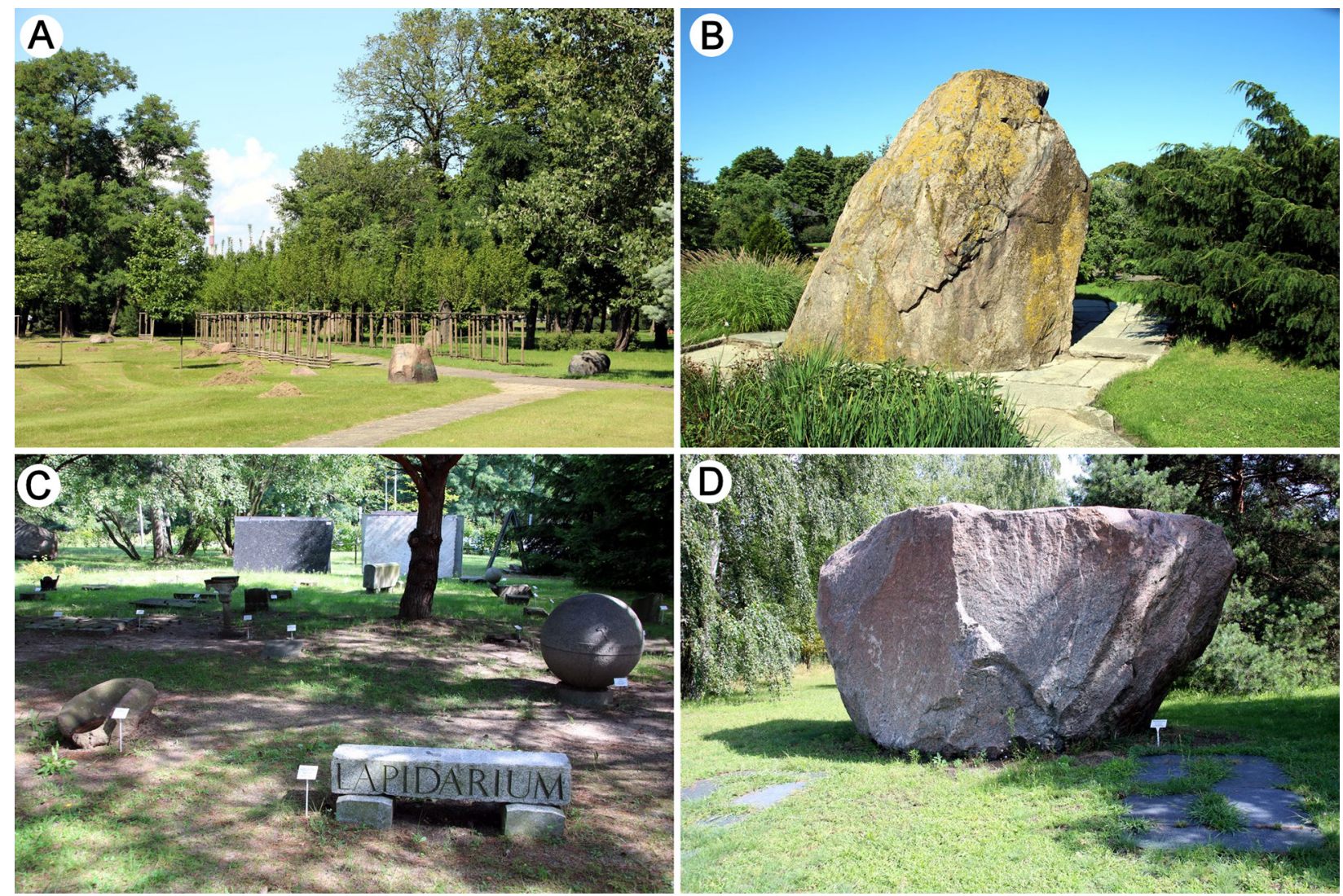

Fig. 5. Urban geosites of postglacial erratics in Poznań (Photo: M. Mazurek, July 2017).

A - collection of erratics in Millenium Park, B - the biggest erratic (gneiss) in Poznań, Botanical Garden of the Adam Mickiewicz University in Poznań, C - Lapidarium of the Institute of Geology of the Adam Mickiewicz University in Poznań, D - indicator erratic (Karlshamn granite) in front of the Institute of Geology of the Adam Mickiewicz University in Poznan.

erratics, such as Dalarna sandstone, Karlshamn granite and Smaland granite (Górska-Zabielska 2010), as well as index erratics, namely Dalarna sandstone (PGI 2017). Boulder surfaces show glacial polish and manifestation of weathering. Boulders are incorporated into tree lines and bushes of the Millennium Park, but their descriptions in the form of information boards are missing. The area is easily accessible and without protection.

\section{Lapidarium at the Institute of Geology}

The rock garden is located in the northern part of Poznań (see Fig. 1, flag 3), in the Morasko Campus near the Institute of Geology, Faculty of Geographical and Geological Sciences of the Adam Mickiewicz University in Poznań. It is part of the Museum of the Earth (Fig. 5 C). The geosite is registered in the Polish Central Register of Geosites under the number KDG: 1253 and the name "Petrographic lapidarium of the Institute of Geology of the University of Adam Mickiewicz in Poznań". Under the open sky, there are various natural objects as well as exhibits showing the use of stones in architecture, construction and art. The exhibition is divided into several thematic sections covering: 1 . stone in nature, 2 . stone in architecture and sculpture, 3 . stone in road construction, 4 . utilitarian stone.

In the natural rock section, there are guide boulders, such as Åland rapakivi granite, Karlsham granite and Kalmar sandstone. On the surfaces of many exposed boulders, one can find traces of their glacial transport (glacial polish) as well as the wind and sand erosion (eologliptolites and glyptoliths) and the effects of weathering processes (Górska-Zabielska 2011). In the lapidarium collection there are two boulders distinguished by their size. The first one is granitic gneiss with an aplite vein in the structure of the rock (length $2.9 \mathrm{~m}$, width $3.4 \mathrm{~m}$, height 1.8 $\mathrm{m}$, circumference $8.6 \mathrm{~m}$, volume $9.28 \mathrm{~m}^{3}$, weight ca. 25 tons). It was obtained from the excavation of the Jóźwin Lignite Opencast Mine in Konin, 
and since 1994 has had the status of an inanimate monument. The second object is the Karlshamn granite, the guide boulder of Blekinge in southern Sweden (length $5.4 \mathrm{~m}$, width $3.2 \mathrm{~m}$, height $3 \mathrm{~m}$, circumference $12.6 \mathrm{~m}$, volume $27.11 \mathrm{~m}^{3}$, Górska-Zabielska 2011, Fig. 5 D).

The lapidarium collects various elements of destroyed or rebuilt public buildings (e.g., millstones), sacred buildings, monuments or other buildings from the streets of Poznan. Between the sixteenth and eighteenth centuries, rocks from the south of Sweden were used in sacred objects of Poznań (Walendowski 2004), such as Ordovician red and grey limestone with fossils from the island of Öland. Stonework objects presented in the lapidarium were made of granites (from Strzegom in Poland and Vangi in Sweden), Scandinavian gneisses, limestone (Swedish Ordovician limestone, Belgian black limestone) and marble (from Sławniowice in Poland and Carrara in Italy), sandstones (e.g. from the vicinity of Nowa Ruda in Poland), slate (including Carboniferous phyllites), and travertine. In the lapidarium it is possible to find examples of limestone from Öland, e.g., the floor plate from the church of St. John of Jerusalem and a corner element of the Poznań cathedral. Other exhibited stone objects are the ornament elements from the Imperial Castle made of the sandstone from the Elbe region and Bolesławiec, as well as Strzegom granite, a window sill from the Collegium Minus made of Austrian marble and a fragment of the destroyed monument of Emperor Frederick III made of Swedish Vanga granite. The objects of the University Lapidarium are readily available and described on the information boards. Due to the collected specimens of geological and cultural heritage, the lapidarium has over regional significance.

\section{Morasko Hill}

The geosite "Morasko Hill" is registered in the Polish Central Register of Geosites under the number KDG: 1405 and the name "Moraine hills north of Poznań Morasko Hill" (see Fig. 1, flag 4). The hill is a glaciotectonically pushed culmination section of the frontal moraines, which were formed during the Poznan Phase of the Weichselian Glaciation (Bartkowski, Krygowski 1959, Krygowski 1961, Karczewski 1961, 1976,
Kozarski 1986). Morasko Hill of the altitude of $153.75 \mathrm{~m}$ a.s.l. is the highest late-glacial elevation in the landscape of Poznan, and even the entire Central Wielkopolska. It has unique scenic values (Fig. 6 A). Relative heights in the lowland landscape of Wielkopolska are rather low, but between the elevation of the Morasko Hill and the nearby Warta Gap, they reach over 100 meters (Fig. 6 B). Morasko Hill is built of deformed Neogene and Pleistocene sediments. Its present-day morphology is the result of the processes connected with the activity of the last ice sheet (Weichselian Glaciation), followed by the Holocene morphogenetic processes. The hill, however, originated in the earlier phases of the Quaternary (Stankowski 2011).

The landscape of Morasko Hill is significantly diverse - there are some late-glacial forms, such as frontal moraine hills, moraine plateau, outwash plains, erosion gullies and dead ice

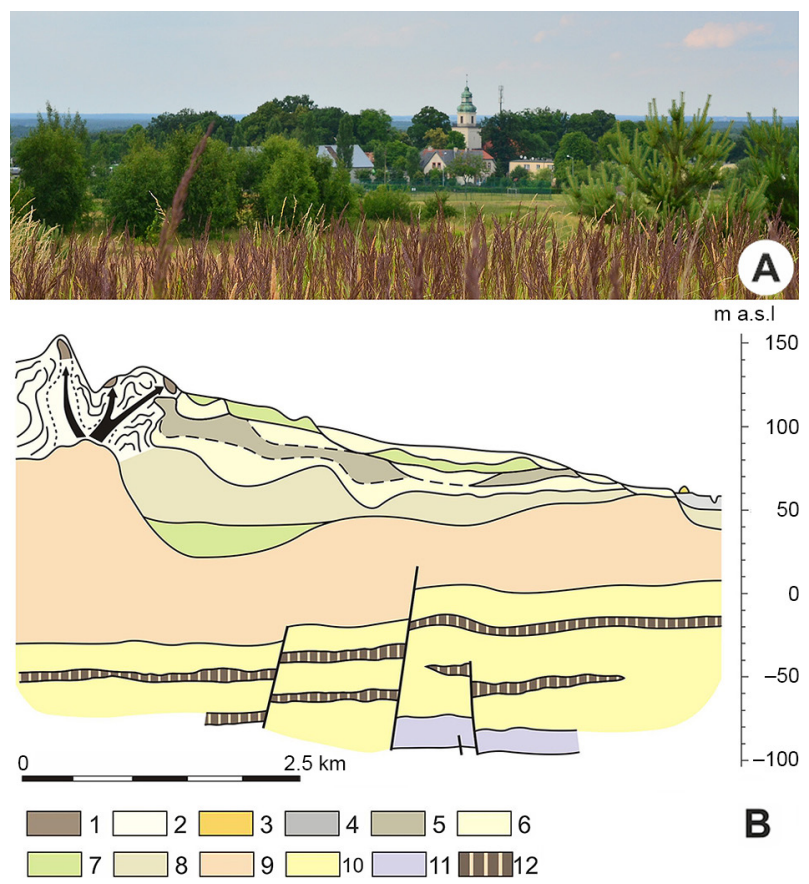

Fig. 6. Urban geosite of the Moraska Góra (Morasko Hill).

A - view on Morasko settlement from the northern slopes of the Morasko Hill, B - schematic geological cross-section through the left bank of morainic upland from Morasko Hill to the Warta River valley (Stankowski 2011, modified): 1 - Neogene deposits within deformations reaching the ground surface, 2 - tills deformed glacitectonically, 3 - eolian snads, 4 finegrained and muddy alluvial sands, 5, 7, 8 - levels of tills, 6 - glaciofluvial deposits, 9 - Neogene clays and muddy deposits, 10 - Neogene sandy brown coal series,

11 - Mesosoic carbonate rocks, 12 - brown coal. 
melt-out basins, as well as boulders found in forests and fields. Boulders have been used since the Middle Ages for local construction. Morasko Hill, due to its exposure in the surrounding landscape, may have played a cultural role in the local community in the past, as may be visible indirectly in the numerous traces of prehistoric settlement occurring in its vicinity (Makohonienko et al. 2016). In the nineteenth century, there was a wooden triangulation station on the culmination of Morasko Hill. The tower will be reconstructed under the planned Morasko Geopark and should favour the perception of landscape values.

\section{Impact Crater Morasko}

The area of Poznan is an example of the presence of endorheic basins of meteorite origin (see Fig. 1, flag 5). They are unique in Poland and one of few in Europe. Such forms occur at the foot of the Morasko Hill and have a depth of up to $11.5 \mathrm{~m}$ (Stankowski 2009). The geosite "Morasko Meteorite" is registered in the Polish Central Register of Geosites under the number KDG: 1406 and the name "Morasko Meteorite Reserve". It is located in the northern part of Poznan, on the northern outskirts of the Morasko Hill. Since 1976, the site has been protected as the impact site in the vicinity of the hornbeam-oak forest, rare in Wielkopolska. The site represents the well-preserved remnants of the meteorite impact that occurred in the middle Holocene, ca. 5,000 years ago (Tobolski 1976, Stankowski 2001, 2008, Szczuciński et al. 2016) (Fig. 7). The Morasko Impact represents the largest documented iron meteorite shower in Central Europe. It is unique in the world due to the presence of impact traces in soft glaciogenic sediments (Muszyński et al. 2014). The site includes seven impact craters, the largest of which reaches a diameter of 100 meters (Fig. 8 A). The described craters are circular and bowl-shaped (Fig. 8B), and display a symmetric distribution around the largest crater (Włodarski et al. 2017, Fig. 9). Some of the craters are continuously or periodically filled with water (Fig. 8 B).

The site of the Morasko impact has been subjected to research for more than a century (Pokrzywnicki 1955, Hurnik 1976, Stankowski 2008, Muszyński et al. 2012). The first meteorite finds were encountered during the excavation of

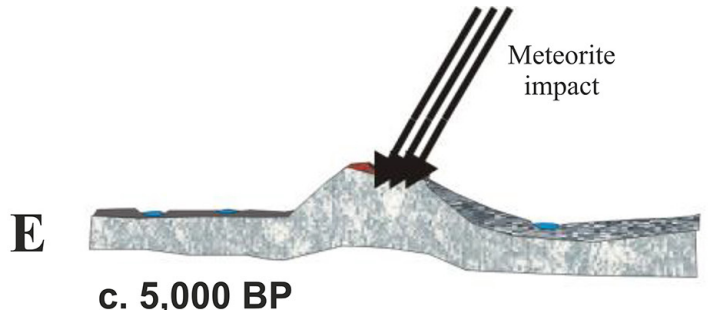

c. $5,000 \mathrm{BP}$

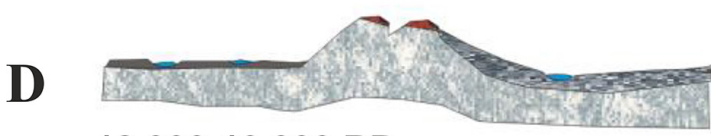

$18,000-10,000$ BP

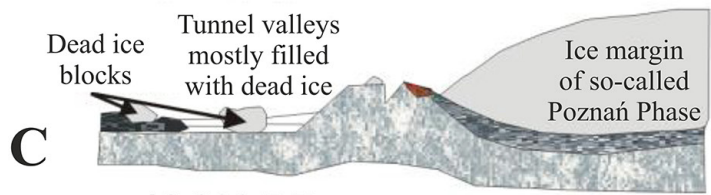

c. $18,000 \mathrm{BP}$

B

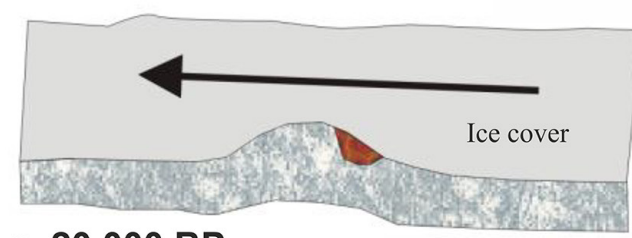

c. $20,000 \mathrm{BP}$

A

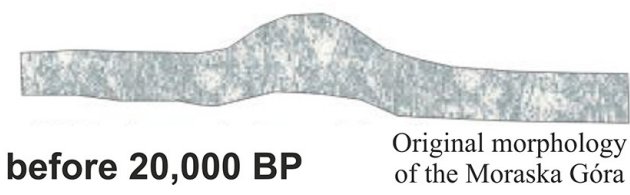

Fig. 7. Timing of main processes and morphological changes of the Morasko Hill during the Vistulian glaciation and Holocene (after Stankowski 2001 and Muszyński et al., 2014, modified).

A - original morphology of the Morasko Hill before the Last Glacial Maximum (LGM) c. 20,000 years ago (the hill originates from glacitectonical deformations in older glaciations and subsequent denudational transformations). B - period of maximum extend of the last ice-sheet reaching so-called Leszno Phase during LGM (the hill covered by ice-sheet. Shallow deformations and ice abrasion surfaces developed. Subglacial meltwater erosional forms have begun to create). C - period of deglaciation during so-called Poznań Phase c. 18,000 years ago (geomorphological processes: prolongation of evorsion, active erosion of melting waters and accumulation of glaciogenic sediments. Out of glacial cover permafrost exist and active periglacial processes occur). D - period of permafrost degradation, development of kettle-holes.

Beginning of organic infilling of kettle-holes $(14,000$ and later) but not younger than 10,000 BP. E - meteorite impact episode about 5,000 years BP (meteorite Morasko shower fell-craters were formed and their organic infilling could start). 

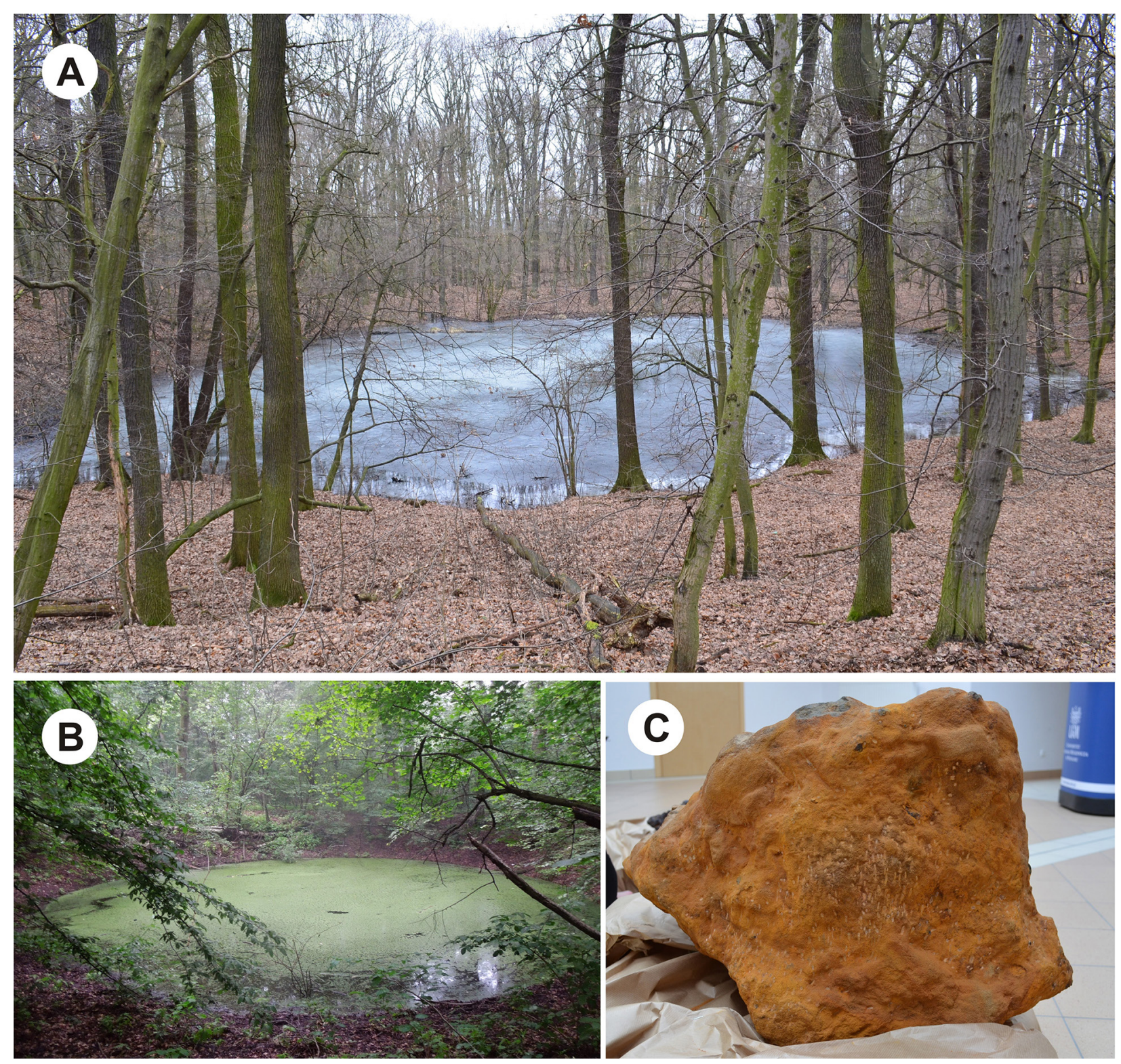

Fig. 8. Urban geosite of the Impact Crater Morasko (Photo: M. Makohonienko).

A - the biggest crater A filled with water surrounded by a protected oak-horn forest (March 2013), B - crater C filled with water (July 2012), C - the largest fragment of Morasko meteorite weighing $261 \mathrm{~kg}$; specimen before cleaning weighing over $300 \mathrm{~kg}$ (October 2012).

Fig. 9. Spatial distribution of main impact craters in Morasko reserve.

1 - dry craters, 2 - craters permanently or occasionally filled with water, 3 - swamp.

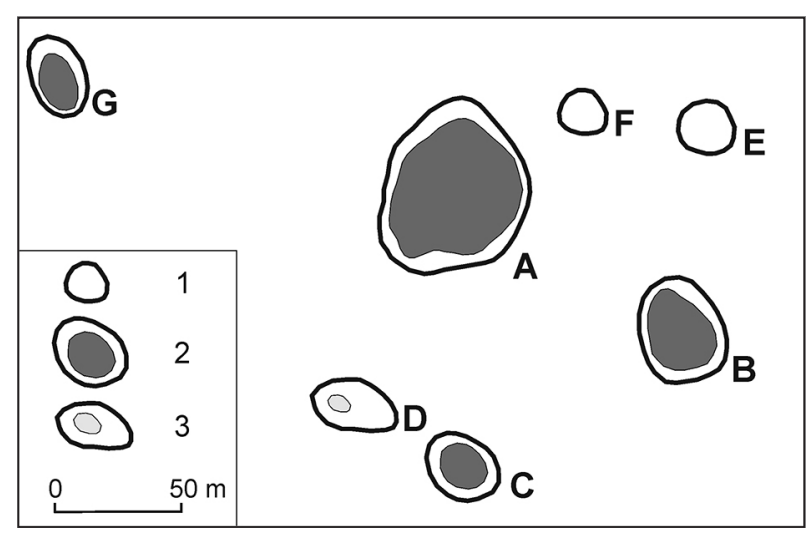


military trenches during the First World War in 1914. The total weight of the finds is estimated today at about $1,500 \mathrm{~kg}$. This site was the source of the largest meteorite fragment found in Poland, weighing $261 \mathrm{~kg}$, presented at the Earth Museum, Faculty of Geographical and Geological Sciences of the Adam Mickiewicz University in Poznan (Fig. 8 C). In 2013 and 2015, two new minerals were discovered in the Morasko Meteorite: moraskoite $\mathrm{Na}_{2} \mathrm{Mg}\left(\mathrm{PO}_{4}\right) \mathrm{F}$ (Karwowski et al. 2015) and czochralskiit $\mathrm{Na}_{4} \mathrm{Ca}_{3} \mathrm{Mg}\left(\mathrm{PO}_{4}\right)_{4}$ (Karwowski et al. 2016). The site is one of the most appreciated places on the meteoritic map of Poland for both professionals and amateur-hobbyists, deserving of full recognition of international geo-tourism.

\section{Proposed geosites}

Analysing the geodiversity of Poznan in the meaning of geodiversity by Zwoliński (2004), Gray (2013) and others, i.e. geodiversity represented on geomorphological, geological, lithological, hydrogeological, hydrographic, soil, land cover and land use etc. maps, it seems appropriate to distinguish three new geosites (see Fig. 1, white flags). They are key for the Poznan's geological, geomorphological, hydrographic, natural, but also archaeological, historical and cultural development. The particularly intensive development of the city since the turn of the nineteenth and twentieth centuries in demographic and spatial terms (Fig. 10) creates favourable conditions for the establishment of further urban geosites. At present, three new geosites are proposed, two of which are located in the centre of Poznań: Genius

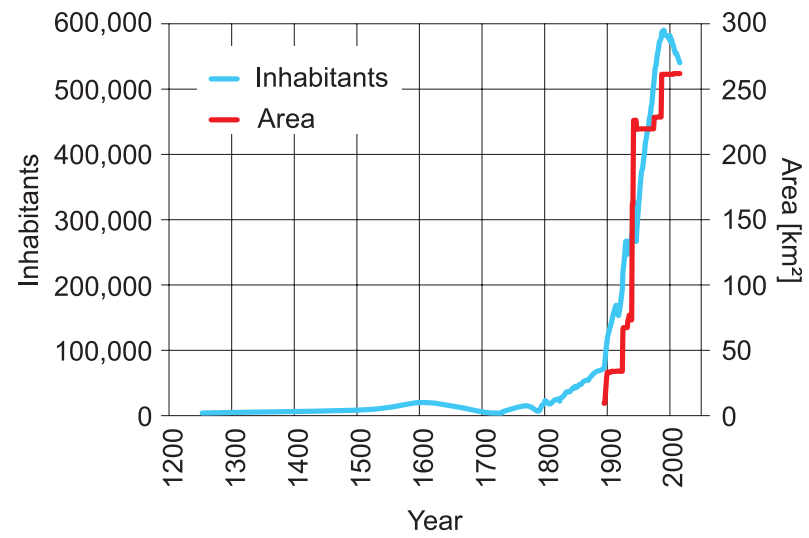

Fig. 10. Changes of inhabitants and area of Poznań city (acc. different historical and statistical data, mainly acc. Kruszka 2008).
Loci and the Poznan section of the Warta River Valley. The third site, the Żurawiniec peat bog, is located at the northern edges of the city.

\section{Genius Loci}

The Genius Loci geosite includes relics of a fragment of a defensive rampart surrounding a medieval gord on Ostrów Tumski Island on the Warta River in Poznań (see Fig. 1, flag 6). At present, this site has the status of the Archaeological Reserve of unique importance, as the face of the city wall is exposed under the modern glass architectural form (Fig. 11 B). The length of all ramparts surrounding the Poznan gord is $2.25 \mathrm{~km}$, and the length of the youngest section, where the geosite is located, $0.5 \mathrm{~km}$ (Fig. $11 \mathrm{~A}$ ). In the exposed part, the sediments of both the foundations of the gord and the anthropogenic sediments that were superimposed in the later stages of the city development can be traced (Fig. 11 C).

The exposure of the cross section gives the possibility of observing these deposits in the horizontal (spatial) as well as vertical (temporal) layout. Geomorphologically it is a floodplain. On this terrace were waterlogged meadows (Antowska-Gorączniak 2013). The hypsometric differences show that the gord was located in the areas prone to frequent floods and periodical stagnation of surface waters, as evidenced by layers of alluvia with malacofauna. The recognised taxa are dominated by those specific for the littoral zone of water bodies with abundant vegetation, e.g., Radix peregra, Gyraulus crista, Acrolorus lacustris, Pisidium nitidum (Kurzawska 2013). Alluvial soil sediments occur at an ordinate of $51.75 \mathrm{~m}$ a.s.l., with an average surface area of approx. $58 \mathrm{~m}$ a.s.l. It can be concluded that about $7 \mathrm{~m}$ of anthropogenic sediments are deposited in the rampart section (Fig. $11 \mathrm{C}$ ). On the other hand, the rampart itself is constructed on an extra sand layer that levels the area and hardened with fascines (branches, bark, wooden roof planks, small stones and braids).

Within the embankment, the primary structural element was five rows of crates in a log buttand-pass structure with an average dimension of $3 \times 3 \mathrm{~m}$. The boxes were filled with sand, sand mixed with till, or till. Excavations have documented three outer rows of crates. It is estimated that the entire width of the embankment could 

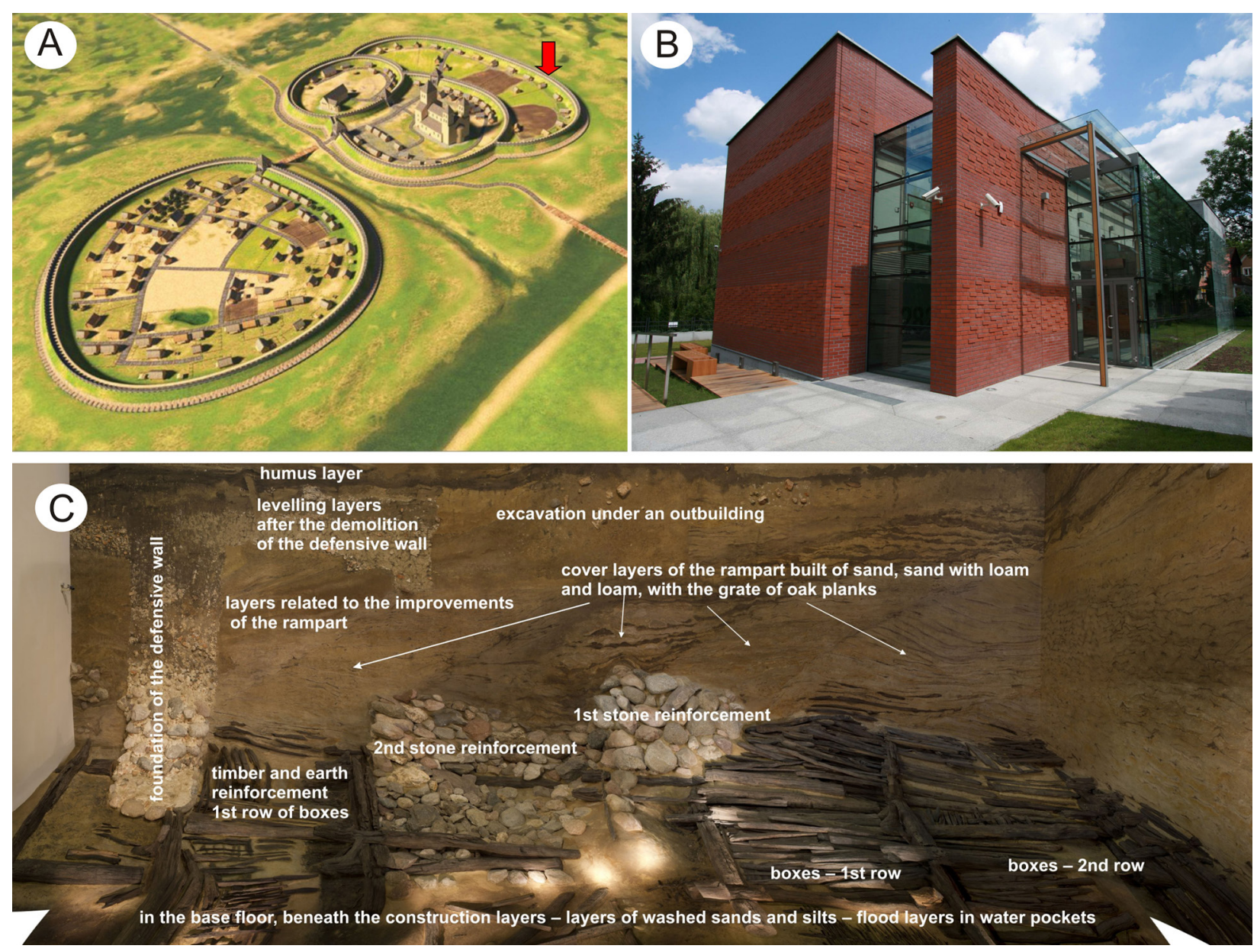

Fig. 11. Proposed urban geosite Genius Loci in Ostrów Tumski, Poznań.

A - model of the stronghold complex reconstruction; the red arrow indicates the location of the proposed geosite (from Archives of the Archaeological Reserve of Genius Loci), B - view of the Genius Loci Archaeological Reserve (inside is the geoarchaeological section shown in picture C) (Photo: I. Hildebrandt-Radke 2017), C - geoarchaeological cross-section through the medieval defence rampart of the stronghold: Profile E (from Archives of the Archaeological Reserve of Genius Loci) (Photo: K. Zisopulu-Bleja 2013).

have reached $22 \mathrm{~m}$, and the height along with the palisade could have been $11 \mathrm{~m}$ (Fig. 11). On the anthropogenic cross section, there are visible humus streaks showing the internal grate structure that has decayed. Covering the construction with till may indicate that the building of the rampart was completed (Antowska-Gorączniak 2013). The till layer on the rampart slope was supposed to protect it against washing and mass movements, and provide fire protection for the wood. However, according to dendrochronological dating, two stone benches and two wooden reinforcements were soon added to the rampart.

Petrographic studies of stone reinforcements indicate their diversity. The first stone reinforcement, older, is made of granites (Scandinavian boulder rocks), in the second bench - a greater share of sandstone and calcareous tufa is noted.
Their share may correspond to the time construction of a palladium or cathedral where such raw materials were used. From the sedimentological cross section, repair steps and degradation processes of the rampart can be reconstructed in the period before the relocation of the settlement to the left bank of the Warta River (i.e., before the town's location in 1253). Probably frequent floods and inundations forced the rampart repair due to the cracking and collapse of the crate construction (Antowska-Gorączniak 2013, Wawrzyniak 2005). Dendrochronological dating places the cutting down of trees used for the building between 967-981 (Krąpiec 2013). The earliest repairs date back to 1001, and the last one - to the middle of the thirteenth century, just before the town's location by Przemysł I on the left bank of the Warta River (Krąpiec 2013). 
A fragment of the sixteenth-century wall was recorded in the ceiling layers of the rampart. Two layers have been preserved: the compensating layer formed as a result of its construction and the post-demolition layer consisting of brick rubble and lime mortar. In various places of archaeological excavation, the sixteenth-century layers are covered by numerous anthropogenic layers from the eighteenth to nineteenth centuries with numerous historical material. The last segment recorded during the excavation research was the humus layer.

The historical value of this place and the modern way of exposing the cross section through the medieval gord wall kept in situ justifies its selection as the proposed geosite.

\section{Żurawiniec peat bog}

The proposed Żurawiniec geosite (see Fig. 1, flag 7) is a unique natural site in the city of Poznan, legally protected since 1959 as a reserve of transition bogs of high educational value (Szafran 1957). The reserve located within the Piątkowski Forest occupies a relatively small area of 1.47 ha with an elongated shape (Żurek 2006) (Fig. 12 A). The peat bog is situated in the late-glacial landscape, in the foreground of the frontal moraine of the Poznan Phase of the Weichselian Glaciation. The ${ }^{14} \mathrm{C}$ dating of the Poznan Phase, and thus the beginnings of shaping the landscape of the northern part of Poznań, is about 18400 years BP (Kozarski 1986). The transition of Żurawiniec bog is located on sand of the Naramowice outwash plain (Żynda 1996), in the basin associated with the fluvioglacial activity. The northern part of the reserve, the largest and best developed with swamp vegetation complexes, was defined by Tomaszewski (1960) as a dead-ice melt basin (Fig. 12 B). As a result of hydrological changes over the last decades, the transition bog flora has been degraded (Siepak et al. 1995). However, the sediments of the Żurawiniec bog still retain a valuable record of the history of the protected geoecosystem and the development of the local cultural landscape dating back to the beginnings of the Polish statehood. These sediments constitute a unique archive of the natural and cultural heritage of the city of Poznan, and in the broader sense of the early history of Poland (Makohonienko 2014).

In 2015 the reserve became a geological reserve. With the cooperation of the city and the Adam Mickiewicz University in Poznan, the project of waterlogging of the reserve for sediment protection and improvement of water conditions is being implemented. In recent years, the Żurawiniec bog and its neighbouring sediments, such as the alder marsh forest bog with the alder-forest (Fig. 13 C) and the former Żurawiniec pond (Fig. 13 A, B), have become field-based
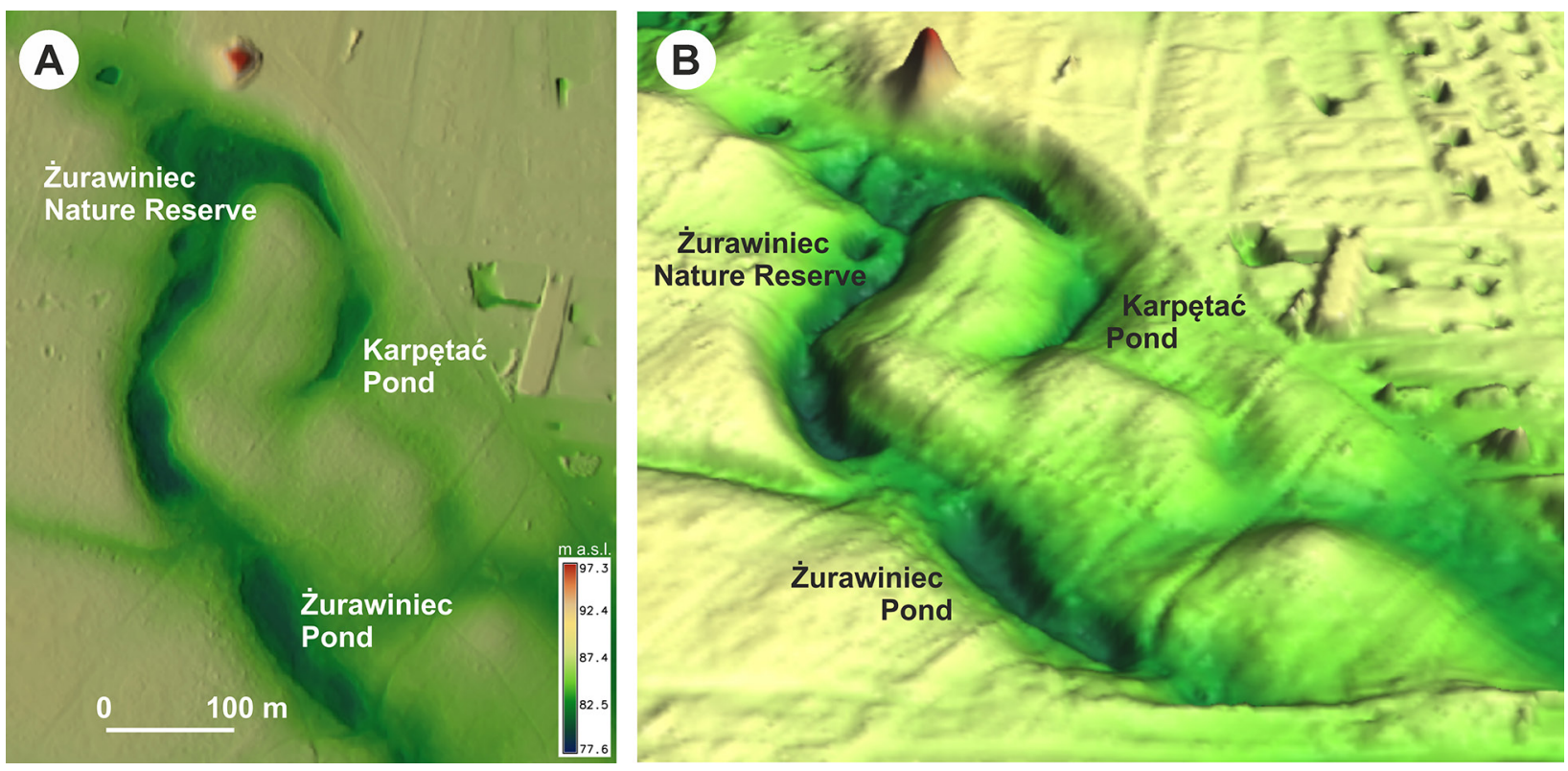

Fig. 12. Digital terrain models of the Żurawiniec Reserve and its immediate vicinity (elaborated on the basis of the ISOK Project by J. Jasiewicz) (after Makohonienko 2014).

A - 2D model, B - 3D model. 

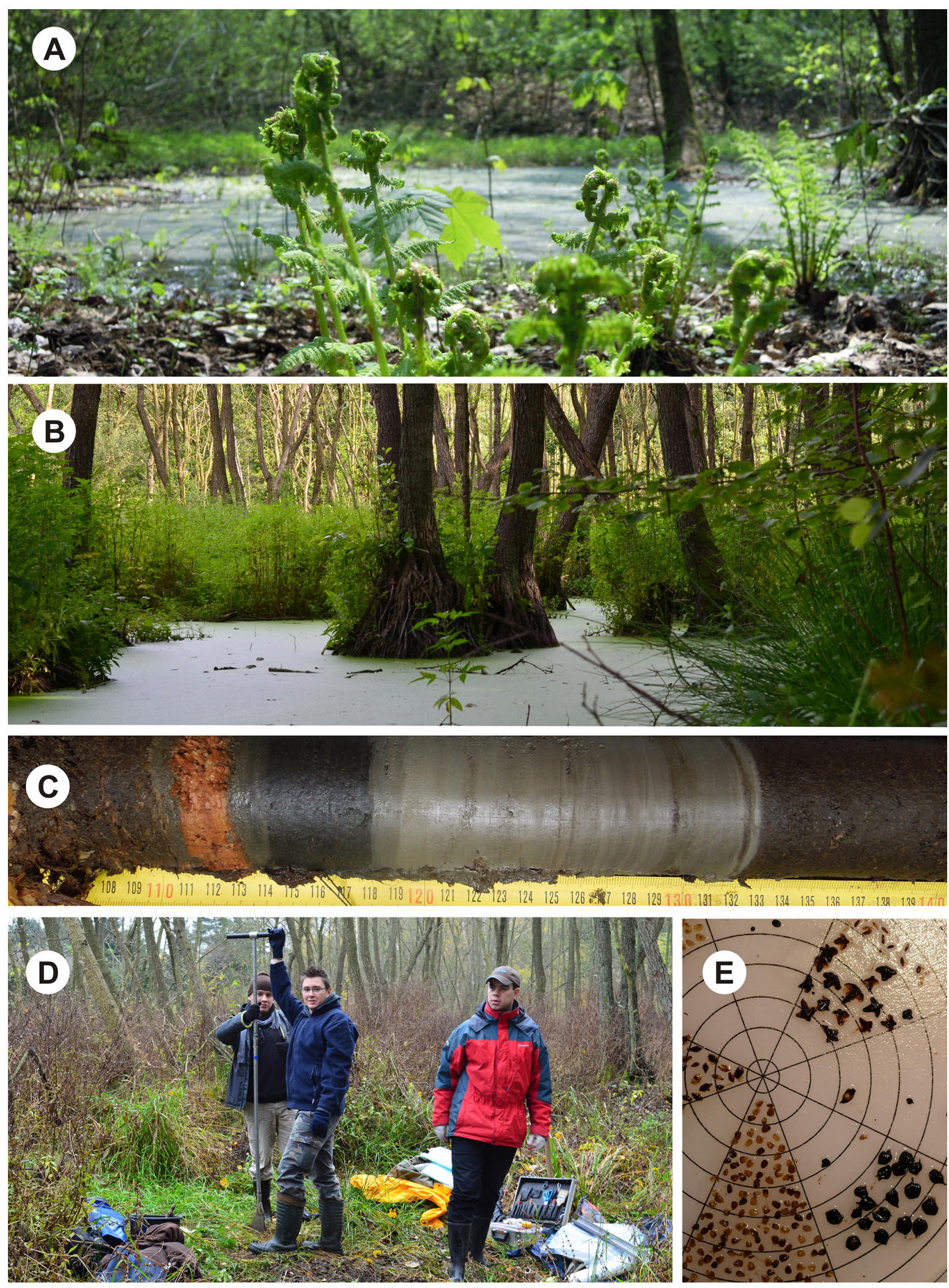

Fig. 13. Proposed urban geosite of the Żurawiniec peat bog.

A - northern part of the Żurawiniec Reserve surrounded by forest communities (May 2015), B - swamp alder forest in the southern part of Piątkowski Forest (August 2016), C - Żurawiniec peat deposits - ZUR 2/2012 core fragment, depth 100-150 cm, D - borehole biogenic sludge drills type INSTORF with the participation of students and PhD students (November 2012), E - macroscopic plant remains from Żurawiniec peat deposits, ZUR 3B/2012 core (Photos A, B, C, D: M. Makohonienko, Photo E: M. Heimann). 
paleoenvironmental research laboratory with active participation of students from the Faculty of Geographical and Geological Sciences (Fig. 13 D). The object is regaining the educational and research dimension popularising paleogeographical knowledge (Fig. 13 D, E).

\section{Poznań section of the Warta River Valley}

The landscape of the gap section of the Warta River valley (see Fig. 1, flag 8), its geological, geomorphological and historical past as well as unique natural values are worthy of establishing a geosite of exceptional importance for the inhabitants of Poznań but also of regional and national significance (Fig. 14 A). The Warta River is an important part of the identity and image of Poznan. The unique spatial pattern of the city is connected with its development along the main morphological axes, such as the south-north-oriented Warta River valley in the so-called Poznan Warta Gap and the diagonal subglacial channels of Bogdanka and Cybina Streams, as well as the Junikowski and Głuszynka Streams (see Fig. 1). These valley forms were formed with a high proportion of melting ice sheets during its recession from the frontal moraine lines of the Poznań Phase during the Weichselian Glaciation. The oldest organic sediments in Warta River valley were accumulated in the Boreal Period, and next in the Atlantic, Subboreal and Subatlantic Periods (Troć, Milecka 2008). Some layers came from the Middle Ages. Similar age was indicated by palynological results and ${ }^{14} \mathrm{C}$ dates as suggested by Troć and Milecka (2008). But in Bogdanka and Cybina valleys palynological results suggest accumulation of organic layers throughout the Holocene to the Middle Ages. There are seven terraces in the Poznań Warta Gap (Bartkowski 1957, Kaniecki 2004, see Fig. 2):

- floodplain (altitude of $53 \mathrm{~m}$ a.s.l., relative height of $0-3 \mathrm{~m}$ above average water level) covering the bottom of a $800 \mathrm{~m}$ wide valley on both sides of the river; it is built of fluvial muds, sand, and gravel; the morphology of this area has been greatly elevated by the construction embankments; the oldest districts of Poznań are located on this terrace: Ostrów Tumski and Śródka (Fig. 14 A);

- terrace II (meadow terrace, the altitude of 55$57 \mathrm{~m}$ a.s.l., the relative height of 3-7 $\mathrm{m}$ above average water level), which is preserved in a small section south of the Bogdanka Stream valley; the left-bank medieval Poznań, translocated from Ostrów Tumski (location rights of 1253), developed in this area;

- terrace III (bifurcation, braided terrace, the altitude of 58-59 $\mathrm{m}$ a.s.1., the relative height of 8-9 $\mathrm{m}$ above average water level), which is fragmentary on the right bank of the Warta River, north of the main river valley;

- terrace IV (erosion terrace dissected in glacial tills, the altitude of 60-64 $\mathrm{m}$ a.s.l., the relative height of 10-14 $\mathrm{m}$ above average water level); in the second half of the twentieth century new districts of the city (Rataje) were built there;

- terrace VI (altitude of 67-70 m a.s.l.; relative height 17-20 $\mathrm{m}$ above average water level), is preserved in a small portion on the right bank in the southern part of the city;

- terrace VII (high, outwash terrace, altitude of 71-73 m, relative height of 21-23 m above the average water Level (acc. to Bartkowski (1957): 19-20 m), whose width is about 1-2 $\mathrm{km}$; a drop of $7 \%$ on the left bank and $5 \%$ on the right; from the lower levels it was separated by sharp edges, but at the turn of the nineteenth and twentieth centuries the terrace was severely softened during the earthworks carried out during the expansion of the city; within it a part of downtown is built (e.g., the area between the Liberty Square and the Main Railway Station).

The sequence of the terrace levels does not have terrace $\mathrm{V}$ because of eroded by fluvial erosion and of the supposed height above the bottom of the valley about $15-16 \mathrm{~m}$. Its traces were found only north of Poznań.

Numerous floods led to the destruction of higher terraces (Bartkowski 1957, Kaniecki 2013). The remains of these levels (e.g., terraces VI and VII), which are higher than the lower terraces, were called "hills", e.g., Gold Hill or Mons Capitula, which are no longer present (Kaniecki 2013).

The original nature of the Warta River valley in Poznań has been strongly transformed by human activity (Kaniecki 2004) (Fig. 14). The distribution of early medieval settlement and the reconstruction of the hydrographical network around Poznan proves that the environmental conditions of the Warta River valley were the factor that 

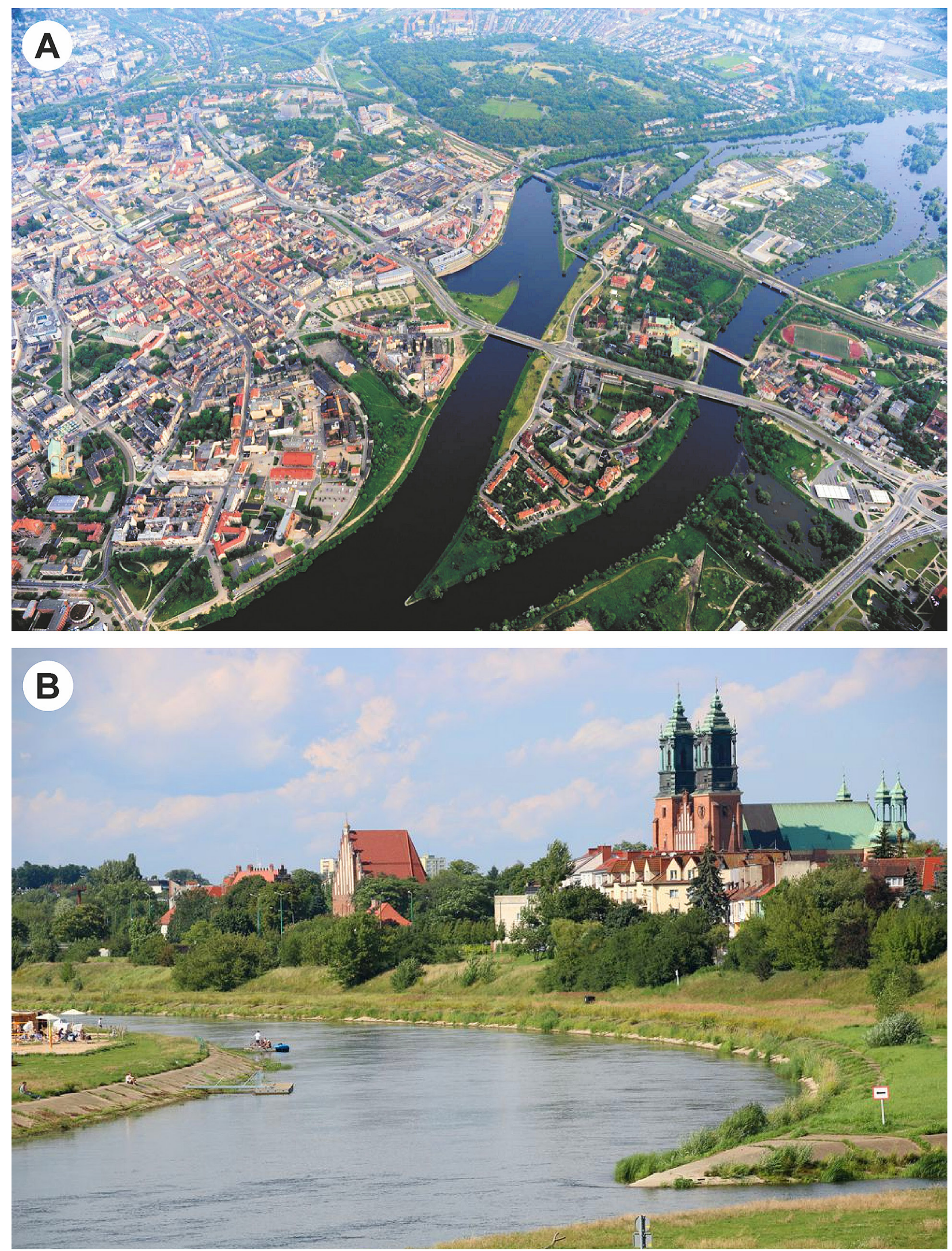

Fig. 14. Proposed urban geosite of the Poznań section of the Warta River Valley.

A - Ostrów Tumski Island was defended during one of the highest flood in June 2010 thanks to the thicker anthropogenic bulk sediments (Photo: Archive of GEOPOZ), B - current management of floodplain, regulated Warta River channel and view on Ostrów Tumski Island from west (visible towers of the Cathedral) (Photo: Zb. Zwolinski 2017). 
decided the location of the gord, from which the most important economic and cultural centre of the Wielkopolska region gradually developed.

Historical records of the floods in Poznań began in 1501. They show that the city was flooded several times. Between 1501 and 1979, 71 flood events were recorded, most of which occurred in the spring (Kaniecki 2004, amended). The greatest flood caused by high summer precipitation took place in 1736 when the water level exceeded 11 $\mathrm{m}$. At the beginning of the twentieth century, the Warta River regulatory works started between Chwaliszewo and Ostrów Tumski; they ended in 1968-1972 (Kaniecki 2004). The Warta River lost its economic importance, it was channelised and gradually become a receiver of various types of sewage from the city. As a result, it became an isolated area. Attractive riverside areas lost historical links with Poznan and therefore turned into a low natural and socio-economic values. The city turned away from its main river. It was not until the 1990s when the role of the natural environment was appreciated that the function and significance of surface waters for the city and its inhabitants was rediscovered.

New trends in urban planning tend to optimise the use of environmental values, especially the water conditions. Poznan, part of the inland waterway of the Grand Loop of Wielkopolska, has particularly favourable conditions for exposing aquatic environmental values. Opportunities for improvement of the current situation are the creation of water protection strategies in urban areas leading to the development of riverside areas and reconstruction of links between the river and the city (e.g., strategic programs "River in the city" and "For the Warta River"). The action plan "For the Warta River" program covers the following six flagship themes: connectivity (traffic and pedestrian areas), river safety, living and working (residential areas and public space), tourism and recreation, historical heritage and landscape, and nature. Within the last themes, it is certainly worth to introduce the urban geosite in the Warta River valley ${ }^{2}$, combining geograph-

Similar environmental conditions were the basis for the development of two other centres of early medieval Europe, namely Paris on the Cite Island on the Seine, France, and Wrocław on the Ostrów Tumski Island in the Odra Valley, Poland (Makohonienko, Kara 2016). ic and historical elements. Previous work to restore nature and history has already contributed to the protection of the unique riverside landscape (Fig. 14).

\section{Assessment of urban geosites - results and discussion}

Both existing and proposed geosites discussed in this article meet the criteria for visibility and invisibility proposed by Clivaz and Reynard (2017). Boulders, though visible today, are not in a landscape position in situ. As a result, they also have features of invisibility. Morasko Mountain and impact craters Morasko are in situ and visible, but their geological and geomorphological history, as well as sometimes cultural history, are invisible to tourists and inhabitants of Poznań today. One should strive to expose these elements of geosites, which can be easily visualised. Although the results of scientific research are trying to explain the idea of how the formation of a glaciotectonic push moraine and meteorite craters could have originated, not all evidence of the evolution of these forms is unequivocal or sufficiently documented. The same applies to the three newly proposed geosites. These geosites can be seen directly in the terrain, but their paleogeographical and historical significance remains in the realm of invisibility.

There are currently many methods for evaluating geosites, which differ in the choice of evaluation criteria, the use of different weights and scoring, and the way in which final grades are calculated, e.g. Alexandrowicz (1989), Bruschi and Cendrero (2005, 2009), Coratza and Giusti (2005), Pralong (2005), Pereira et al. (2007), Reynard et al. (2007, 2016), Knapik et al. (2009), Reynard (2009), Rybár (2010), Baca and Schuster (2011), Bruschi et al. (2011), Fassoulas et al. (2012), Kubaliková (2013), Reynard, Coratza (2013), Pica et al. (2014, 2016, 2017), Rocha et al. (2014), Brilha (2016), Kubaliková and Kirchner (2016). These methods have been reviewed by Kubaliková (2013), Štrba et al. (2014) and partly Migoń and Pijet-Migoń (2017). However, none of these authors indicate which of the methods they discuss should be recommended for evaluation of geosites. Kubaliková (2013) has identified the following groups of criteria for assessing 
geosites: 1 - the scientific and intrinsic values (integrity, rarity; scientific knowledge; morphology, genesis), 2 - the exemplarity and pedagogical potential (exemplarity, clarity; educational facilities; use for education), 3 - accessibility and visibility of the site and the presence of tourist infrastructure (tourist services; local products; accessibility), 4 - the existing threats and risks, assessing conservation activities or the existing legislative protection of the site (conservation activities; risks and threats; current status), and 5 - added values (cultural values; ecological value; aesthetic/landscape value). The author made a quantitative assessment of seven methods presented by Bruschi and Cendrero (2005), Coratza and Giusti (2005), Pralong (2005), Serrano and Gonzales-Trueba (2005), Pereira et al. (2007), Reynard et al. (2007) and Zouros (2007), and concluded that the less relevant methods for assessing geosites and geomorphosites for geotourism purposes are those described by Coratza and Giusti (2005) and Reynard et al. (2007), which use less than half the geosite evaluation criteria outlined by this author. In turn, Kubaliková (2013) described the methods by Pralong (2005) and Pereira et al. (2007) as those best exploiting these assessment criteria.

Somewhat more cautious in evaluating the used methods are Štrba et al. (2014). They divide the methods into two groups: qualitative and quantitative, but do not indicate the best ones (Pereira et al. 2007, Reynard et al. 2007, Rybár 2010, Baca and Schuster 2011, Bruschi et al. 2011, Fassoulas et al. 2012). They do, however, define the criteria, which should be taken into account in the assessment of geosites. According to these authors, these should be: 1 - rarity (uniqueness), 2 - representatives (complete and expressive manifestation of a geo(morpho)logical phenomenon), 3 - integrity (current state of the site), 4 - accessibility (limitation or special permissions), 5 - ecological value (presence of ecotypes and level of the site protection), and 6 - economic value (sustainable development of (geo)tourism). In the selection of these criteria, the authors were primarily directed by the uniformity and universality of the method that reduces the subjectivity of the evaluator. Probably this approach to choosing the criteria is more appropriate than the right choice from among the various methods used.
Migoń and Pijet-Migoń (2017) note that the methods they are discussing (Bruschi and Cendrero 2005, 2009; Pereira et al. 2007; Reynard 2009; Brilha 2016; Kubaliková and Kirchner 2016; Reynard et al. 2016), concentrate mainly on 1 the scientific value of a site, 2 - its educational potential, and 3 - accessibility, and refer to geological and geomorphological features. These authors develop the concept of the geosites assessment concerning viewpoints, paying attention to the role of geodiversity in the context of Ollier's (2012) opinion. As a result, a single form of low geodiversity may have a higher rating than a diverse landscape without morphological or geological individuality. Undoubtedly, this situation can be met by the existing geosites of Poznan depicting erratic boulders. On the other hand, for the majority of geosites, Migon and Pijet-Migon (2017) attach importance to observation points which show the panoramic scenery of a given place/landscape.

By analysing the views presented by Kubaliková (2013), Štrba et al. (2014) and Migoń and Pijet-Migon (2017), it is hard to find the best evaluation method of geosites. Considering the objectives of this article, the methods developed by Pica et al. $(2014,2017)$ need thinking, because they concern urban geosites. To test the objectivity of the methods used, the results of their evaluations were compared with one of the existing geosite assessment methods analysed by these authors. Selection is difficult as mentioned, but assuming that the simplest possible methods are usually most reliable (similar to the idea of geoindicators and bioindicators), the choice of reference method for comparison with the one of Pica and co-authors seems to indicate the method developed by Reynard et al. (2007), which earned only seven points in Kubaliková's classification (2013). Simplicity, compactness and relatively quick evaluation allow this method to be ranked as a reference. The method of Reynard et al. (2007) has two parts of assessment: qualitative and quantitative. The quantitative section includes:

1. scientific value (integrity, representativeness, rareness, paleogeographical value),

2. additional values:

a. ecological value: ecological impact and protected site, 
b. aesthetic value: view points and contrasts, vertical development and space structuration,

c. cultural value: religious importance, historical significance, artistic and literature importance, geo-historical importance, and

d. economic value: economic products.

Each criterion is evaluated on a scale from 0 to 1 , with 0 being no value and 1 being the maximum value of the standard.

For urban areas, methodological suggestions by Pica et al. $(2014,2017)$ seem to exhaust a set of issues for such places. The article by Pica et al. (2014) discusses an interesting approach to geomorphological geosites in the urban context. This method combines geomorphological and historical views with geotourism. The authors delimit five criteria:

- Representativeness (RP) - shows the relationship between the geological phenomena represented in the geosite and the ideal model of the same geological phenomenon in nature, and also defines peculiarity of the phenomena and its various facets;

- Rarity (RR) - is the relationship between the frequency of the geological phenomenon and the geographical condition of the phenomenon;

- Scenic-aesthetic value (SCE) - quantifies the attractiveness of the geosite from a specialist and non-specialist point of view, and is an attribute of the fast perception of individuality of the area, but at the same time it is hard to quantify because of its strong connection to emotions;

- Storical-Archeological-Cultural value (SAC) is a function of the geosite relationship with local history and culture;

- Accessibility (AC) - depends on the difficulty of reaching the geosite and the presence of nearby services.

Based on these criteria, the Value of a site for Geotourism index (VSG index, Pica et al. 2014) is calculated:

$$
\mathrm{VSG}=\mathrm{RP}+\mathrm{RR}+\mathrm{SCE}+\mathrm{SAC}+\mathrm{AC} .
$$

The second method by Pica et al. (2017) refers to urban geomorphic heritage assessment method, which considers the following criteria:

- Representativeness (RP) - including geo-scientific value (the site is a landform representative of anthropogenic and morphogenetic process); landscape evolution (the site is a landform representative of anthropogenic and morphogenetic process); city image (the site is a landform representative of anthropogenic and morphogenetic process),

- Visibility (V) - the landform is recognisable in the landscape,

- Geohistorical reconstruction significance (GeoHIS) - the site is documented and represented in historical records (early maps, paintings, archaeological maps, etc.) that highlight the human impact on landscape transformations),

- Aesthetic peculiarity of the urbanised context (AP) - the shape of the landform is visually disconnected from the context and attract the attention and curiosity of observatory,

- Touristic attractiveness rate (TAR) - the site is a tourist attraction, much visited by people for its features and information about geo-aspects undoubtedly increase its interest.

Similarly, the Value of a site for Geotourism index is now calculated according to the following:

$$
\mathrm{VSGh}=\mathrm{RP}+\mathrm{V}+\mathrm{GeoHIS}+\mathrm{AP}+\mathrm{TAR} .
$$

Pica et al. (2017) in their article do not make any suggestion to the number of points assigned to each of the characteristics in question. Consequently, the same scores were used as in the article of Pica et al. (2014), ie on a scale of $1-5$. It means that the VSG and VSGh indexes can take values between 5 and 25. Pica et al. (2014) assign these indexes three classes which range as follows:

1. from 1 to 8 - low value,

2. from 9 to 16 - medium value, and

3. from 17 to 25 - high value of the geosite.

It is roughly the division of points into three equal classes. This type of group is not eligible in this case, since the vast majority of geosites are of the "high" or "medium" level, while few geosites are in the "low" class. Hence, it is necessary to 
extend the lowest class. The authors of this paper propose the following breakdown:

1. low class - from 5 to 15 ,

2. medium class - from 16 to 20 , and

3. high class - from 21 to 25 .

It is worth noting that the calculated VSG index may take values from 5 upwards. It means that they will never take values from 0 to 4 , since each criterion may have the lowest value of 1 and therefore never reach 0 . In the light of the calculated Tabular Accuracy Indexes (TAI, acc. Jenks, Caspall 1971) the proposed division into classes is more efficient than this given by Pica et al. (2014) (Table 1). The best fit of the class ranges is close to 1 (Jenks, Caspall 1971). The proposed range of classes for the three geosite assessment methods analysed shows that the TAI values range from $0.75-0.87$ and are on average 0.21 higher than for the Pica's class ranges.

The results of evaluation of existing and proposed urban geosites in Poznań calculated by three methods according to Reynard et al. (2007), Pica et al. (2014) and Pica et al. (2017) are listed in Table 2. Comparison of the two methods by Pica and co-authors' and the reference method by
Reynard et al. (2007) shows that all the methods keep more or less the same trend of geosite rating, i.e., they take relatively similar values for a single geosite (Fig. 15). An example of such geosite is the Warta River valley. In turn, the biggest differences in evaluations should be noted for the three geosites created by lapidaries. Total geosite ratings vary for all methods in the same range, i.e., 13, 12 and 14 points. Existing urban geosites

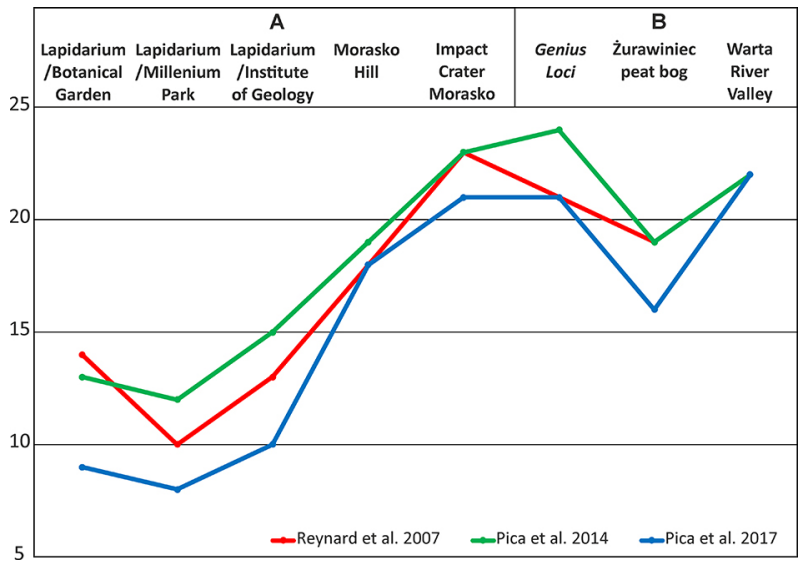

Fig. 15. Comparison of assessments for existing (A) and proposed (B) urban geosites in Poznań obtained from three methods by different authors.

Table 1. Effectiveness of class spanning in urban geosites assessment on the basis of the Tabular Accuracy Index (TAI) according to formula by Jenks and Caspall (1971).

\begin{tabular}{|c|c|c|c|c|c|c|}
\hline \multirow{3}{*}{ Intervals } & \multicolumn{6}{|c|}{ Assessment of existing and proposed urban geosites in Poznań according } \\
\hline & \multicolumn{2}{|c|}{ Reynard et al. (2007) } & \multicolumn{2}{|c|}{ Pica et al. (2014) } & \multicolumn{2}{|c|}{ Pica et al. (2017) } \\
\hline & $\begin{array}{c}\text { Number } \\
\text { of used classes }\end{array}$ & TAI & $\begin{array}{c}\text { Number } \\
\text { of used classes }\end{array}$ & TAI & $\begin{array}{c}\text { Number } \\
\text { of used classes }\end{array}$ & TAI \\
\hline 1-8, 9-16, 17-25 (Pica et al. 2014) & 2 & 0.58 & 2 & 0.57 & 3 & 0.66 \\
\hline $5-15,16-20,21-25$ (this paper) & 3 & 0.75 & 3 & 0.82 & 3 & 0.87 \\
\hline
\end{tabular}

Table 2. Comparison of assessments for existing and proposed urban geosites in Poznań obtained from three methods by different authors.

\begin{tabular}{|c|c|c|c|}
\hline \multirow{3}{*}{ Geosites } & \multicolumn{3}{|c|}{ Final values } \\
\hline & $\begin{array}{l}\text { Referenced method } \\
\text { Reynard et al. (2007) }\end{array}$ & $\begin{array}{c}\text { VSG index } \\
\text { Pica et al. (2014) }\end{array}$ & $\begin{array}{c}\text { VSGh index } \\
\text { Pica et al. (2017) }\end{array}$ \\
\hline & \multicolumn{3}{|c|}{ Scores } \\
\hline \multicolumn{4}{|c|}{ Existing geosites } \\
\hline Lapidarium/Botanical Garden & $\left(0.57^{*}\right) 14^{* *}$ & 13 & 9 \\
\hline Lapidarium/Millenium Park & $(0.38) 10$ & 12 & 8 \\
\hline Lapidarium/Institute of Geology & $(0.51) 13$ & 15 & 10 \\
\hline Morasko Hill & $(0.72) 18$ & 19 & 18 \\
\hline Impact Crater Morasko & $(0.91) 23$ & 23 & 21 \\
\hline \multicolumn{4}{|c|}{ Proposed geosites } \\
\hline Genius Loci & $(0.84) 21$ & 24 & 21 \\
\hline Żurawiniec peat bog & $(0.76) 19$ & 19 & 16 \\
\hline Warta River Valley & $(0.87) 22$ & 22 & 22 \\
\hline
\end{tabular}

* the original values according to Reynard et al. (2007) are in parentheses; ** values converted against the maximum scale according to Pica et al. (2014), i.e. 25. 
(an average of 15 according to three methods) were rated on average six points lower than the proposed ones (an average of 21 points by three methods). Such a significant difference in favour of the proposed urban geosites corroborates with the prevailing opinion on the need for a rapid legal change of the status of these geosites.

The VSG index values are, on average, 0.88 ( -3 to 1 ) below the reference values, while the VSGh index values are, on average, 1.88 (from 0 to 5) higher than the reference values (Fig. 15). This means that the method proposed by Pica et al. (2017) is actually more focused on urban geosites.

\section{Concluding remarks}

Considering the geomorphological and hydrographical conditions, the northern part of Poznan is the most varied regarding the landscape. Its important feature is the glaciotectonically pushed moraine of the Poznan Phase of the Weichselian Glaciation, and the lake waters filling the meteorite craters and subglacial channels. Two urban geosites are located in this area, namely Morasko Hill and, within its borders, impact craters. However, at present, these areas are subject to settlement pressure, as it is one of the main directions of housing investment in Poznań. With the glacial past of the landscape of Poznan and its environs, there are three other urban geosites in the form of lapidariaes. They are a particular type of moveable geosites.

The biodiversity of Wielkopolska's landscape was conducive to the location of Poznan and influenced its further development. The Warta River valley and its tributaries were the settlement drive, as they form a particular hydrographic node connecting the areas lying on the river or directly at the bottom of the Warta River valley. These areas were the earliest inhabited and intensively transformed, so the natural character of the valley as a concave form with the terrace system has been modified by levelling and raising the terraces, where the largest thicknesses of the anthropogenic layers are observed today. Poznan was born in the Warta River valley and today, after many years of turning away from the river, it is turning towards it by proposing the creation of an urban geosite in the very river valley. The second proposed urban geosite, namely Genius Loci, is located on one of the islands in the bottom of the Warta River valley. The large spatial hydrographic node in Poznań is full of natural and artificial reservoirs and wetlands. One such wetland filled with peat, Żurawiniec, is proposed for the third urban geosite within Poznan.

The most valuable urban geosites in Poznan are the existing impact crater Morasko and the proposed Genius Loci. They can be classified as the highest rated urban geosites, with a total of over 20 scores. These geosites show unique natural and historical values, and - from the geodiversity standpoint - represent a natural and anthropogenic form of terrain, respectively. The undoubted strengths of these geosites are representativeness, rarity as well as good management (especially Genius Loci) and relatively easy access for the residents and tourists. Indeed, these geosites should be given a European rank. The third extremely valuable urban geosite will be the proposed Warta River valley, with which the inhabitants of Poznań try to identify again after a few decades of the break, appreciating the place of birth of the city and subsequent expansion into neighbouring areas of moraine plateaus with the valley, first to the west and then east.

In addition to the existing and proposed urban geosites in Poznan, there are many other forms of terrain created by human activity. Such anthropogenic forms, which should evoke interest in the near future, include the 22 military forts, mainly from the second half of the nineteenth century. Together with the enormous Citadel, they constitute the-then most modern Prussian fortress, an example of military architecture with ground reworks. The other form worth paying attention to in the future, are 40 disused pits, turned into artificial water bodies and associated aquatic ecosystems. They are connected with the excavation of till on flat moraine plateau at the beginning of the twentieth century, and are known in the local dialect as shafts (szachty in Polish) (now ecological utility).

\section{Acknowledgements}

The authors are grateful to two anonymous reviewers for their useful comments that allowed us to improve our previous version of the manuscript. 


\section{References}

Alexandrowicz Z. (ed.), 1989. Ochrona przyrody i krajobrazu Karpat polskich. Studia Naturae ser. B 33: 1-241.

Alexandrowicz Z., 2004. Important geosites of Poland in relation to the ecological network Natura 2000. Polish Geological Institute Special Papers 13: 41-48.

Antowska-Gorączniak O., 2013. Badania na stanowisku przy ul. Posadzego 5 w 2009/2010 r. - charakterystyka nawarstwień. In: Kóčka-Krenz H. (ed.), Poznań we wczesnym średniowieczu, 8. Wydawnictwo Nauka i Innowacje, Poznań: 19-60.

Bâca I., Schuster E., 2011. Listing, evaluation and touristic utilisation of geosites containing archaeological artefacts. Case study: Ciceu ridge (Bistrita- Nasaud County Romania). Revista Geografica Academica 5(1): 5-20.

Bartczak E., 1993. Szczegółowa Mapa Geologiczna Polski w skali 1:50 000, arkusz Kórnik z objaśnieniami. PIG, Warszawa.

Bartkowski T., 1957. Rozwój polodowcowej sieci hydrograficznej w Wielkopolsce Środkowej. Zeszyty Naukowe UAM w Poznaniu, Geografia 8(1): 3-79.

Bartkowski T., Krygowski B., 1959. Próba kartograficznego ujęcia geomorfologii najbliższej okolicy Poznania. Zeszyty Naukowe UAM, Geografia 2(21): 87-94.

Biedrowski Z., 1968. Sandry okolic Poznania. Studium geomorfologiczno-sedymentologiczne. UAM, Poznań, MS PhD Thesis.

Brilha J., 2016. Inventory and quantitative assessment of geosites and geodiversity sites: a review. Geoheritage 8: 119-134. DOI: 10.1007/s12371-014-0139-3.

Bruschi V.M., Cendrero A., 2005. Geosite evaluation; can we measure intangible values? Il Quaternario 18(1): 293-306.

Bruschi V.M., Cendrero A., 2009. Direct and parametric methods for the assessment of geosites and geomorphosites. In: Reynard E., Coratza P., Regolini-Bissig G. (eds.), Geomorphosites. Dr. Friedrich Pfeil Verlag, Munich: 73-88.

Bruschi V.M., Cendrero A., Albertos J.A.C., 2011. A statistical approach to the validation and optimization of geoheritage assessment procedures. Geoheritage 3: 131-149. DOI: 10.1007/s12371-011-0038-9.

Chachaj J., 1996. Szczegótowa Mapa Geologiczna Polski w skali 1:50 000, arkusz Mosina z objaśnieniami. PIG, Warszawa.

Chmal R., 1992. Szczegótowa Mapa Geologiczna Polski w skali 1:50 000, arkusz Stęszew z objaśnieniami. PIG, Warszawa.

Chmal R., 1996. Szczegótowa Mapa Geologiczna Polski, arkusz 471 - Poznań (N-33-130-D). PIG, Warszawa.

Chmal R., 1997. Objaśnienia do Szczegótowej Mapy Geologicznej Polski, arkusz 471 - Poznań (N-33-130-D). PIG, Warszawa.

Chybiorz R., Kowlaska M., 2017. Od inwentaryzacji geostanowisk, przez bazę danych, do produktu geoturystycznego. In: Jawecki B., Tarka R. (eds.), GEO-PRODUKT od geoedukacji do innowacji. Geopark Przedgórze Sudeckie, Piława Górna: 6-15.

Cincio Z., 1996. Szczegótowa Mapa Geologiczna Polski w skali 1:50 000, arkusz Swarzędz z objaśnieniami. PIG, Warszawa.

Ciuk E., 1978. Geologiczne podstawy dla nowego zagłębia węgla brunatnego w strefie rowu tektonicznego PoznańCzempiń-Gostyń. Przegląd Geologiczny 26: 588-594.

Clivaz M., Reynard E., 2017. How to Integrate Invisible Geomorphosites in an Inventory: a Case Study in the
Rhone River Valley (Switzerland). Geoheritage: 1-15. DOI: 10.1007/s12371-017-0222-7.

Coratza P., Giusti C., 2005. Methodological proposal for the assessment of the scientific quality of geomorphosites. Il Quaternario 18(1): 307-313.

Czubla P., Gałązka D., Górska M., 2006. Eratyki przewodnie w glinach morenowych Polski. Przegląd Geologiczny 54(4): 245-255.

Dyjor S., 1970. Seria poznańska w Polsce Zachodniej. Kwartalnik Geologiczny 14(4): 818-833.

Fassoulas Ch., Mouriki D., Dimitriou-Nikolakis P., Iliopoulos G., 2012. Quantitative Assessment of Geotopes as an Effective Tool for Geoheritage Management. Geoheritage 4: 177-193. DOI: 10.1007/s12371-011-0046-9.

Gogołek W., 1993. Szczegółowa Mapa Geologiczna Polski w skali 1:50 000, arkusz Buk z objaśnieniami. PIG, Warszawa.

Górska-Zabielska M., 2008. Fennoskandzkie obszary alimentacyjne osadów akumulacji glacjalnej i glacjofluwialnej lobu Odry. Wydawnictwo Naukowe UAM, Poznań.

Górska-Zabielska M., 2010. Głazy narzutowe Wielkopolski. Prace i Studia z Geografii i Geologii, 18. Bogucki Wydawnictwo Naukowe, Poznań.

Górska-Zabielska M., 2011. Ogródki petrograficzne w Poznaniu i najbliższej okolicy. In: Ratajczak-Szczerba M. (ed.), Człowiek $i$ środowisko. Studium interdyscyplinarne. Studia $\mathrm{i}$ Prace z Geografii i Geologii, 19. Bogucki Wydawnictwo Naukowe, Poznań: 99-107.

Górska-Zabielska M., 2013. Geowalory Ogrodu Botanicznego UAM w Poznaniu. Badania Fizjograficzne, Geografia Fizyczna A64: 51-65. DOI: 10.2478/bfpz-2013-0004.

Górska-Zabielska M., 2015. Najcenniejsze głazy narzutowe w Wielkopolsce i ich potencjał geoturystyczny. Przeglad Geologiczny 63(8): 455-463.

Gray M., 2013. Geodiversity: Valuing and Conserving Abiotic Nature. John Wiley \& Sons Ltd, Chichester.

Grocholski W., 1991. Budowa geologiczna przedkenozoicznego podłoża Wielkopolski. Przewodnik 62 Zjazdu PTG, Poznań: 7-18.

Hildebrandt-Radke I., 2016. Środowisko geograficzne Poznania. In: Kara M., Makohonienko M., Michałowski A. (eds.), Przemiany osadnictwa $i$ środowiska przyrodniczego Poznania i okolic od schyłku starożytności do lokacji miasta. Bogucki Wydawnictwo Naukowe, Poznań: 23-46.

Hurnik H. (ed.), 1976. Meteorite Morasko and the region of its fall. Adam Mickiewicz University Press, Poznań, Ser. Astronomia 2: 1-64.

Jenks G.F., Caspall F.C., 1971. Error on choroplethic maps: definition, measurement, reduction. Annals of the Association of American Geographers 61(2): 217-244.

Kaniecki A., 2004. Poznań. Dzieje miasta woda pisane. Cz. I-III. Wydawnictwo PTPN, Poznań.

Kaniecki A., 2013. Wpływ antropopresji na przemiany środowiskowe w dolinie Warty w Poznaniu. Landform Analysis 24: 23-34. DOI: 10.12657/landfana.024.003.

Karczewski A., 1961. Morasko Hill - example of a terminal push moraine of the Poznan stage. $V^{\text {th }}$ Congress INQUA, GuideBook A: 21-22.

Karczewski A., 1976. Morphology and lithology of closed depression area located on the northern slope of Morasko Hill near Poznań. In: Hurnik H. (ed.), Meteorite Moras$k o$ and the region of its fall. Adam Mickiewicz University Press, Poznań, Ser. Astronomia 2: 7-20.

Karwowski Ł., Kryza R., Muszyński A., Kusz J., Helios K., Drożdżewski P., Galuskin E.V., 2016. Czochralskiite, $\mathrm{Na}_{4} \mathrm{Ca}_{3} \mathrm{Mg}\left(\mathrm{PO}_{4}\right)_{4}$, a second new mineral from the Moras- 
ko IAB-MG iron meteorite (Poland). European Journal of Mineralogy 28(5): 969-977. DOI: 10.1127/ ejm/2016/00282557.

Karwowski Ł., Kusz J., Muszyński A., Kryza R., Sitarz M., Galuskin E. V., 2015. Moraskoite $\mathrm{Na}_{2} \mathrm{Mg}\left(\mathrm{PO}_{4}\right) \mathrm{F}$, a new mineral from the morasko IAB-MG iron meteorite (Poland). Mineralogical Magazine, 79(2): 387-398. DOI: 10.1180/minmag.2015.079.2.16.

Kirchner K., Smolová I., 2010. Základy antropogenní geomorfologie. Univerzita Palackého v Olomouci, 287 p.

Knapik R., Jała Z., Sobczyk A., Migoń P., Aleksandrowski P., Szuszkiewicz A., Krąpiec M., Madej S., Krakowski K., 2009. Opracowanie metodyki waloryzacji i waloryzacja geostanowisk Karkonoskiego Parku Narodowego i jego otuliny. In: Inwentaryzacja i waloryzacja geostanowisk Karkonoskiego Parku Narodowego i jego otuliny oraz wykonanie mapy geologicznej tego obszar obszaru. MS.

Kozarski S., 1986. Skale czasu a rytm zdarzeń geomorfologicznych vistulianu na Niżu Polskim. Czasopismo Geograficzne 52(2): 247-270.

Kozarski S., 1995. Deglacjacja północno-zachodniej Polski: warunki środowiska i transformacji geosystemu ( 20ka-10ka BP). Dokumentacja Geograficzna, 1.

Kóčka-Krenz H., 2015a. Poznań - od grodu do miasta. Archeologia Histotrica Polona 23: 121-138. DOI: 10.12775/ AHP.2015.005.

Kóčka-Krenz H., 2015b. Proces formowania się państwa Piastów. Folia Praehistorica Posnaniensia XX: 205-218. DOI: 10.14746/fpp.2015.20.12.

Krąpiec M., 2013. Dendrochronologiczne datowanie wału grodu poznańskiego na podstawie drewna wyeksplorowanego podczas badań prowadzonych przy ulicy ks. Posadzego 5 w 2009 r. In: Kóčka-Krenz H. (ed.), Poznań we wczesnym średniowieczu, 8. Wydawnictwo Nauka i Innowacje, Poznań: 285-292.

Kruszka K., 2008. Statystyczna karta historii Poznania. Urząd Statystyczny w Poznaniu, $257 \mathrm{p}$.

Krygowski B., 1961. Geografia fizyczna Niziny Wielkopolskiej. Cz. I. Geomorfologia. Poznańskie Towarzystwo Przyjaciół Nauk, Wydział Matematyczno-Przyrodniczy, Poznań: 204 p.

Kubalíková L., 2013. Geomorphosite assessment for geotourism purposes. Czech Journal of Tourism 2(2): 80-104. DOI: 10.2478/ cjot-2013-0005.

Kubaliková L., Kirchner K., 2016. Geosite and geomorphosite assessment as a tool for geoconservation and geotourism purposes: a case study from Vizovická vrchovina Highland (Eastern Part of the Czech Republic). Geoheritage 8: 5-14. DOI: 10.1007/s12371-015-0143-2.

Kubalíková L., Kirchner K., Bajer A. 2017. Secondary geodiversity and its potential for urban geotourism: a case study from Brno city, Czech Republic. Quaestiones Geographicae 36(3): 63-73. DOI: 10.1515/quageo-2017-0024.

Kunkel A. 1975. Osady iłowe neogenu młodszego Wielkopolski środkowej w świetle bibułowej chromatografii rozdzielczej. Poznańskie Towarzystwo Przyjaciół Nauk, Prace Komisji Geograficzno-Geologicznej 14, Warszawa-Poznań.

Kurzawska A., 2013. Analiza malakologiczna. In: Kóčka-Krenz H. (ed.), Poznań we wczesnym średniowieczu, 8. Wydawnictwo Nauka i Innowacje, Poznań: 331-336.

Makohonienko M., 2014. Opracowanie inwentaryzacyjne osadów biogenicznych jako wytyczne do projektu budowalno-wykonawczego nawodnienia Rezerwatu Żurawiniec $i$ jego otoczenia (Lasku Piątkowskiego) poprzez wykorzystanie wód opadowych z kanatów burzowych. Zakład Lasów Poznańskich, MS.

Makohonienko M., Kara M., Hildebrandt-Radke I., Jasiewicz J., Antczak-Górka B., Michałowski A., 2016. Rozwój wczesnomiejskich założeń środkowej Wielkopolski - środowisko i gospodrka miasta Poznania rekonstruowana na podstawie archiwów kopalnych. Zarys problematyki. In: Kara M., Makohonienko M., Michałowski A. (eds.), Przemiany osadnictwa i środowiska przyrodniczego Poznania i okolic od schyłku starożytności do lokacji miasta. Bogucki Wydawnictwo Naukowe, Poznań: 13-21.

Makohonienko M., Kara M., Hildebrandt-Radke I., Jasiewicz J., Antczak-Górka B., Michałowski A., 2016. Środowiskowe uwarunkowania lokalizacji osadnictwa pra- i protohistorycznego (głównie wczesnośredniowiecznego) na obszarze obecnego Poznania w świetle źródeł archeologicznych - dyskusja wybranych zagadnień. In: Kara M., Makohonienko M., Michałowski A. (eds.), Przemiany osadnictwa $i$ środowiska przyrodniczego Poznania i okolic od schyłku starożytności do lokacji miasta. Bogucki Wydawnictwo Naukowe, Poznań: 257-294.

Migoń P., Pijet-Migoń E., 2017. Viewpoint geosites - values, conservation and management issues. Proceedings of the Geologists' Association 128(4): 511-522. DOI: 10.1016/j. pgeola.2017.05.007.

Motta L., Motta M., 2007. Erratic blocks: from protector beings to geosites to be protected. Geological Society, London, Special Publications 273(1): 315-327. DOI: 10.1144/GSL. SP.2007.273.01.24.

Muszyński A., Kryza R., Karwowski Ł., Pilski A.S., Muszyńska J. (eds.), 2012. Morasko. The largest iron meteorite shower in Central Europe. Bogucki Wydawnictwo Naukowe, Poznań: 111 p.

Muszyński A., Stankowski W., Szczuciński W., 2014. Field excursion to the "Morasko Meteorite" Reserve. Mars - Connecting Planetary Scientists in Europe, Poznań, 6 June 2014: 1-11.

Ollier C.D., 2012. Problems of geotourism and geodiversity. Quaestiones Geographicae 31(3): 57-61. DOI: 10.2478/ v10117-012-0025-5.

Pawłowski S., 1929. Rozważania nad morfologią doliny Warty pod Poznaniem. Badania Geograficzne nad Polską Pótnocno-Zachodnia 4-5: 91-106.

Pereira P., Pereira D., Caetano Alves M.I., 2007. Geomorphosite assessment in Montesinho Natural Park (Portugal). Geographica Helvetica 62: 159-168.

Pica A., Fredi P., Del Monte M., 2014. The Ernici Mountains Geoheritage (Central Apennines, Italy): Assessment of the Geosites for Geotourism Development. Geojournal of Tourism and Geosites VII/2(14): 176-189.

Pica A., Luberti G.M., Vergari F., Fredi P., Del Monte M., 2017. Contribution for an urban geomorphoheritage assessment method: proposal from three geomorphosites in Rome (Italy). Quaestiones Geographicae 36(3): 21-36. DOI: 10.1515/quageo-2017-0030.

Pica A., Vergari F., Fredi P., Del Monte M., 2016. The Aeterna Urbs Geomorphological Heritage (Rome, Italy). Geoheritage 8(1): 31-42. DOI: $10.1007 /$ s12371-015-0150-3.

PIG [Polish Geological Institue - National Research Institute], 2017. Central Register of Geosites of Poland. Online: http://geoportal.pgi.gov.pl/portal/page/ portal/geostanowiska (accessed 12 July 2017).

Pokrzywnicki J., 1955. O niektórych mało znanych polskich meteorytach. Studia Geologica Polonica 3: 427-438. 
Pożaryski W., 1974. Podział obszaru Polski na jednostki tektoniczne. In: Pożaryski W. (ed.), Budowa geologiczna Polski. T. 4. Tektonika. Cz. 1. Niż Polski: 24-34.

Pralong J.P., 2005. A method for assessing tourist potential and use of geomorphological sites. Géomorphologie: relief, processus, environnement 11(3): 189-196.

Reynard E., 2004. Geosite. In: Goudie A.S. (ed.), Encyclopedia of Geomorphology, vol. 1. Routledge, London, p. 440.

Reynard E., 2009. The assessment of geomorphosites. In: Reynard E., Coratza P., Regolini-Bissig G. (eds.), Geomorphosites. Dr. Friedrich Pfeil Verlaeg, Munich: 63-71.

Reynard E., Coratza P., 2013. Scientific research on geomorphosites. A review of the activities of the IAG working group on geomorphosites over the last twelve years. Supplementi di Geografia Fisica e Dinamica Quaternaria 36(1):159-168. DOI: 10.4461/GFDQ.2013.36.13.

Reynard E., Fontana G., Kozlik L., Scapozza C., 2007. A method for assessing the scientific and additional values of geomorphosites. Geographica Helvetica 62(3): 148-158. DOI: 10.5194/gh-62-148-2007.

Reynard E., Perret A., Bussard J., Grangier L., Martin S., 2016. Integrated approach for the inventory and management of geomorphological heritage at the regional scale. Geoheritage 8: 43-60. DOI: 10.1007/s12371-015-0153-0.

Reynard E., Pica A., Coratza P., 2017. Urban geomorphological heritage. An overview. Quaestiones Geographicae 36(3): 7-20. DOI: 10.1515/quageo-2017-0022.

Rocha J., Brilha J., Henriques M.H., 2014. Assessment of the geological heritage of Cape Mondego Natural Monument (Central Portugal). Proceedings of the Geologists' Association 125(1): 107-113. DOI: 10.1016/j.pgeola.2013.04.005.

Rybár P., 2010. Assessment of attractiveness (value) of geotouristic objects. Acta Geoturistica 1(2): 13-21.

Serrano E., Gonzáles-Trueba J.J., 2005. Assessment of geomorphosites in natural protected areas: the Picos de Europa National Park (Spain). Géomorphologie: relief, processus, environnement 11(3): 197-208.

Siepak J., Staniewska-Zątek W., Sobczyński T., Barałkiewicz D., 1995. Degradacja roślinności w Rezerwacie Żurawiniec w Poznaniu jako efekt antropopresji. In: Kaniecki A., Rotnicka J. (eds.), Wody powierzchniowe Poznania, Sorus, Poznań: 389-397.

Stankowski W., 2001. The geology and morphology of the natural reserve "Meteoryt Morasko". Planetary and Space Science 49: 749-753.

Stankowski W., 2008. Morasko meteorite a curiosity of the Poznan region. Time and results of the fall. Adam Mickiewicz University Press, Poznań, Ser. Geologia 19: 91 p.

Stankowski W., 2009. Meteoryt Morasko. Wydawnictwo Naukowe UAM, Poznań

Stankowski W., 2011. Rezerwat Meteoryt Morasko - morfogeneza kosmiczna zagłębień terenu. Landform Analysis 16: 149-154.

Štrba L., Rybár P., Baláž B., Molokáč M., Hvizdák L., Kršák B., Lukáč M., Muchová M., Tometzová D., Ferenčíková J., 2014. Geosite assessments: comparison of methods and results. Current Issues in Tourism 18(5): 496-510. DOI: 10.1080/13683500.2014.882885.
Sydow S., 1996. Szczegótowa Mapa Geologiczna Polski w skali 1:50 000, arkusz Murowana Goślina z objaśnieniami. PIG, Warszawa.

Szabó J., Dávid L., Loczy D. (eds), 2010. Anthropogenic Geomorphology. A Guide to Man-Made Landforms. Springer, Dordrecht, $250 \mathrm{p}$.

Szafran H., 1957. Żurawiniec rezerwat dydaktyczny w Poznaniu. Przyroda Polski Zachodniej 1: 100-104.

Szczuciński W., Pleskot K., Makohonienko M., Tjallingii R., Apolinarska K., Cerbin S., Goslar T., Nowaczyk N., Rzodkiewicz M., Słowiński M., Woszczyk M., Brauer A., 2016. Environmental effects of small meteorite impact in unconsolidated sediments - case of iron meteorite shower in Morasko, Poland. 79th Annual Meeting of the Meteoritical Society, Berlin: paper 6433: 1.

Tobolski K., 1976. Palynological investigations of the bottom sediments in closed depressions Meteorite Morasko and the region of its fall. In: Hurnik H. (ed.), Meteorite Moras$k o$ and the region of its fall. Adam Mickiewicz University Press, Poznań, Ser. Astronomia 2: 21-26.

Tomaszewski E., 1960. Mapa Geomorfologiczna Polski w skali 1:50 000, arkusz Poznań i Kostrzyn. Galon R. (ed.), Instytut Geografii PAN.

Troć M., Milecka K., 2008. Wiek osadów aluwialnych doliny Warty oraz doliny Cybiny i Bogdanki w rejonie śródmieścia w Poznaniu. Badania Fizjograficzne nad Polską Zachodnią ser. A 59: 145-160.

Walendowski H., 2004. Szwedzkie wapienie z Olandii w Wielkopolsce. Nowy Kamieniarz: 46-50.

Warowna J., Migoń P., Kołodyńska Gawrysiak R., Kiebała A., Zgłobicki W., 2013. Geomorphosites of Poland - the role played by the Central Register of Geosites. Landform Analysis 22: 117-124. DOI: 10.12657/landfana.022.010.

Wawrzyniak P., 2005. Badania wykopaliskowe wczesnośredniowiecznych umocnień wałowych przy ul. Ks. Ignacego Posadzego nr 5 na Ostrowie Tumskim w Poznaniu w latach 2001-2004. In: Kóčka-Krenz H. (ed.), Poznań we wczesnym średniowieczu, 5. Poznań: 91-110.

Włodarski W., Papis J., Szczuciński W., 2017. Morphology of the Morasko crater field (western Poland): Influences of pre-impact topography, meteoroid impact processes, and post-impact alterations. Geomorphology 295: 586-597. DOI: 10.1016/j.geomorph.2017.08.025.

Zouros N., 2007. Geomorphosite assessment and management in protected areas of Greece. Case study of the Lesvos Island - coastal geomorphosites. Geographica Helvetica 62(3): 169-180. DOI: 10.5194/gh-62-169-2007.

Zwoliński Zb., 2004. Geodiversity. In: Goudie A.S. (ed.), Encyclopedia of Geomorphology, vol. 1. Routledge, London: 417-418.

Żurek S., 2006. Katalog rezerwatów przyrody na torfowiskach Polski. Wydawnictwo Akademii Świętokrzyskiej. Kielce: $202 \mathrm{p}$.

Żynda S., 1996. Rzeźba terenu, geomorfologia. In: May J., Stelmasiak S., Ludwiczak I., Niezborała M. (eds.), Środowisko naturalne miasta Poznania, część 1. Urząd Miejski w Poznaniu. Wydział Ochrony Środowiska, Poznań: 15-22. 